\title{
$100 \%$ Fruit juice and measures of glucose control and insulin sensitivity: a systematic review and meta-analysis of randomised controlled trials
}

\author{
Mary M. Murphy ${ }^{1}$, Erin C. Barrett ${ }^{1,2} \dagger$, Kara A. Bresnahan ${ }^{1}$ and Leila M. Barraj ${ }^{1}$ \\ ${ }^{1}$ Exponent, Inc., Center for Chemical Regulation \& Food Safety, 1150 Connecticut Avenue, NW, Washington, DC 20036, USA \\ ${ }^{2}$ Habit, LLC, 985 3rd Street, Oakland, CA 94607, USA
}

(Received 29 April 2017 - Final revision received 14 September 2017 - Accepted 11 October 2017)

Journal of Nutritional Science (2017), vol. 6, e59, page 1 of 15

doi:10.1017/jns.2017.63

Abstract

Studies on the effects of consuming $100 \%$ fruit juice on measures of glycaemic control are conflicting. The purpose of the present study was to systematically review and quantitatively summarise results from randomised controlled trials (RCT) examining effects of $100 \%$ fruit juice on glucose-insulin homeostasis. Eligible studies were identified from a systematic review of PubMed and EMBASE and hand searches of reference lists from reviews and relevant papers. Using data from eighteen RCT, meta-analyses evaluated the mean difference in fasting blood glucose (sixteen studies), fasting blood insulin (eleven studies), the homeostatic model assessment of insulin resistance (HOMA-IR; seven studies) and glycosylated Hb (HbA1c; three studies) between the $100 \%$ fruit juice intervention and control groups using a random-effects model. Compared with the control group, $100 \%$ fruit juice had no significant effect on fasting blood glucose $(-0.13(95 \% \mathrm{CI}-0 \cdot 28,0 \cdot 01) \mathrm{mmol} / \mathrm{l} ; P=0 \cdot 07)$, fasting blood insulin $(-0 \cdot 24(95 \% \mathrm{CI}-3 \cdot 54$, $3.05) \mathrm{pmol} / \mathrm{l} ; P=0.89)$, HOMA-IR $(-0.22(95 \% \mathrm{CI}-0.50,0 \cdot 06) ; P=0.13)$ or HbA1c $(-0.001(95 \% \mathrm{CI}-0 \cdot 38,0 \cdot 38) \% ; P=0 \cdot 28)$. Results from stratified analyses and univariate meta-regressions also largely showed no significant associations between $100 \%$ fruit juice and the measures of glucose control. Overall, findings from this meta-analysis of RCT suggest a neutral effect of $100 \%$ fruit juice on glycaemic control. These findings are consistent with findings from some observational studies suggesting that consumption of $100 \%$ fruit juice is not associated with increased risk of diabetes.

Key words: 100 \% Fruit juice: Fasting blood glucose: Fasting blood insulin: Insulin sensitivity: Homeostatic model assessment of insulin resistance

Worldwide, the number of people with diabetes is rising. In 2014, the estimated prevalence among adults was $8 \cdot 5 \%$, which is approximately double the prevalence of $4.7 \%$ in $1980^{(1)}$. Due to its prevalence and associated complications, diabetes is a well-recognised public health concern ${ }^{(2)}$. Overweight and obesity are the strongest risk factors for type 2 diabetes (T2D), though lifestyle and dietary modification also are recognised strategies that may delay or prevent development of the disease.

Controversy and uncertainty have been expressed within the scientific community as to what effect, if any, $100 \%$ fruit juice may have on health including risk for diabetes ${ }^{(3)}$. Pure $(100 \%)$ fruit juices can be nutrient-dense foods providing $\mathrm{K}, \mathrm{Mg}$, folate, $\mathrm{Ca}$, vitamins $\mathrm{A}$ and $\mathrm{C}$, and soluble fibre as well as an array of bioactive substances including carotenoids and flavonoids ${ }^{(4-6)}$. Nutritional guidance encourages consumption of fruit as part of a balanced and healthy diet, although guidance often recommends limited consumption of fruit in the form of juice citing concerns over a lack of fibre and the potential for excessive energy intake ${ }^{(7)}$. Juices also tend to have moderately high-glycaemic index ratings ${ }^{(8)}$, indicating a relatively rapid and high post-prandial glucose response as compared with foods with a lower glycaemic index, and diets lower in these types

Abbreviations: HbA1c, glycosylated Hb; HOMA-IR, homeostatic model assessment of insulin resistance; RCT, randomised controlled trial; T2D, type 2 diabetes.

*Corresponding author: M. M. Murphy, fax +1 202772 4979, email mmurphy@exponent.com

† Erin C. Barrett was an employee of Exponent, Inc. at the time of this study.

(C) The Author(s) 2017. This is an Open Access article, distributed under the terms of the Creative Commons Attribution licence (http://creativecommons.org/licenses/by/4.0/), which permits unrestricted re-use, distribution, and reproduction in any medium, provided the original work is properly cited. 
of simple carbohydrates may be relevant for the prevention and management of some chronic diseases including $\mathrm{T} 2 \mathrm{D}^{(9)}$. However, results from in vitro and animal studies suggest that polyphenols may favourably affect glucose-insulin homeostasis through a variety of mechanisms ${ }^{(10)}$. The net effect of $100 \%$ fruit juice on glucose metabolism and biomarkers of diabetes therefore reflects a complex interplay of numerous factors.

Results from human studies of associations between $100 \%$ fruit juice consumption and risk of T2D or effects on diabetes biomarkers have been conflicting. A recent meta-analysis of thirteen prospective cohorts reported no association between consumption of fruit juice and incident T2 $\mathrm{D}^{(11)}$. When further adjusted for obesity, the meta-analysis showed a $7 \%$ increased risk for incident $\mathrm{T} 2 \mathrm{D}$, though the presence of significant heterogeneity limits the quality of this evidence ${ }^{(11)}$.

No meta-analysis of randomised controlled trials (RCT) with a specific focus on $100 \%$ fruit juices has been identified. Wang et al. ${ }^{(12)}$ reported finding no significant effect on glycaemic control and blood insulin in a meta-analysis of twelve RCT collectively described as $100 \%$ fruit juice. The analysis included studies using juice products other than $100 \%$ fruit juice ${ }^{(12)}$, namely beverages prepared from freeze-dried whole fruit which provided a substantial source of dietary fibre $^{(13,14)}$, beverages prepared from fruit juice sweetened using no-energy sweeteners ${ }^{(15,16)}$, and a study in which both the test and control beverages were prepared from $100 \%$ fruit juice ${ }^{(17)}$. The identified meta-analysis therefore was not exclusively based on RCT of $100 \%$ fruit juice compared with a non-juice control. Several years have passed since completion of the meta-analysis and recent clinical trials examining the effects of $100 \%$ fruit juice consumption on glucose-insulin homeostasis provide further insight into the role of juice on biomarkers of diabetes risk.

The purpose of the present study was to systematically review the literature to identify RCT in which effects of $100 \%$ fruit juice on measures of glucose control and insulin sensitivity have been examined and, based on the totality of evidence, to re-evaluate in a meta-analysis the effects of $100 \%$ fruit juice on these biomarkers for diabetes risk.

\section{Methods}

\section{Literature search and study selection}

The present systematic review and meta-analysis followed the Preferred Reporting Items for Systematic Reviews and Meta-Analyses (PRISMA) statement ${ }^{(18)}$. A comprehensive literature search was conducted to identify clinical studies examining the relationship between the consumption of $100 \%$ fruit juice and measures of glucose-insulin homeostasis, with no exclusions based on age, ethnicity or health status of the study population. A pre-specified protocol is not available for this study. The search of PubMed was conducted with terms (juice[TIAB] OR juices[TIAB]) AND ('controlled trial' OR 'clinical trial' OR crossover OR cross-over OR random*) with no limits other than English-language papers. The search of EMBASE was conducted using similar terms. Terms for specific measures of glucose control or insulin sensitivity were not included in the search string to allow for identification of studies in which measures of interest were collected as secondary outcomes or in the course of routine patient monitoring. The initial search was conducted on 23 March 2015, and searches were updated on 14 April 2016. Supplemental literature searches included review of reference lists in relevant studies and pertinent review articles and correspondence with researchers in the field.

The search results were screened independently by two investigators (M. M. M., E. C. B.) for eligible studies and discrepancies were resolved by consensus. Clinical trials were eligible if the following criteria were met: (1) the trial was randomised and conducted in human subjects; (2) the trial was a controlled intervention providing $100 \%$ fruit juice and a control beverage (e.g. sugar/carbohydrate or energy-matched beverage, water, or no beverage); (3) the fruit juice consumed was identified as $100 \%$ fruit juice (including single-strength juice prepared from concentrate or a blend of $100 \%$ fruit juices) or any juice specified by name such as, but not limited to, apple, blueberry, cherry, cranberry, grape, grapefruit, orange, pear, pomegranate or strawberry juice; (4) subjects consumed $100 \%$ fruit juice for a minimum of 2 weeks; (5) outcome data for at least one measure of glucose control or insulin sensitivity were reported; and (6) reported outcomes included change from baseline values or baseline and endpoint values with error terms. Tomato juice was not included as a fruit juice in this analysis as it is typically marketed as a vegetable juice.

\section{Data extraction}

All eligible studies were reviewed and pertinent data were extracted, including: name of the first author, publication year, study design, geographic location of the intervention, demographic and health characteristics of the study population (e.g. age, sex, presence of obesity or a chronic disease, BMI), sample size, intervention duration, juice type, a description of the control product, and outcomes measured. Additional data extracted from the studies included sugar content of the $100 \%$ fruit juice and control beverages, volume of juice consumed per $\mathrm{d}$, baseline fasting blood glucose level, information on randomisation, double-blinding, and withdrawals and dropouts to develop quality scores of each study based on the Jadad criteria ${ }^{(19)}$. Information on funding was reviewed to determine if the research was completed with support from industry funding, including donation of study product. Data extraction was completed independently by one investigator and reviewed for accuracy by another (M. M. M. and E. C. B. or K. A. B.). The extracted information included that provided by study investigators in response to requests for missing data and study details ${ }^{(20-23)}$. Fasting blood glucose, fasting blood insulin, the homeostatic model assessment of insulin resistance (HOMA-IR), glycosylated $\mathrm{Hb}(\mathrm{HbA} 1 \mathrm{c})$ and other reported measures of glucose-insulin homeostasis (oral glucose tolerance test, insulinogenic and Matsuda indices) were captured as change from baseline or as baseline and postintervention values. Fasting glucose values were converted to 
$\mathrm{mmol} / 1$ assuming $1 \mathrm{mg} / \mathrm{dl}=0 \cdot 05551 \mathrm{mmol} / \mathrm{l}$. Fasting insulin values were converted to $\mathrm{pmol} / 1$ assuming $1 \mu \mathrm{U} / \mathrm{ml}=6 \cdot 0$ $\mathrm{pmol} / \mathrm{l}^{(24)}$.

\section{Statistical analysis}

A meta-analysis was conducted to quantify the effects of consumption of $100 \%$ fruit juice on each measure of glucose control or insulin sensitivity reported in at least three studies. The meta-analysis evaluated the mean difference from baseline and end of treatment values between the $100 \%$ juice treatment and control group of fasting blood glucose, fasting blood insulin, HOMA-IR and HbA1c. The $I^{2}$ statistic was used to assess statistical heterogeneity between studies.

For studies not reporting the change from baseline to the end of intervention in both the treatment and control groups, the mean difference was calculated as (Treatment ${ }_{\text {end }}-$ Treatment $\left.t_{\text {baseline }}\right)-\left(\right.$ Control $_{\text {end }}-$ Control $\left._{\text {baseline }}\right)$. The method described by Curtin et al. ${ }^{(25)}$ was used to estimate the mean difference and associated standard error from the combined parallel and cross-over studies. A pooled estimate of the variance of the mean difference was estimated for each study. For parallel studies, the estimate was derived using the reported estimates of the standard errors or the calculated standard errors as derived from the reported CI estimates. For crossover studies when estimates of the standard deviation (or standard error) were only available for baseline and post- intervention measurements, the pooled variance was estimated using standard errors for the intervention and control groups and an imputed correlation coefficient of $0 \cdot 5^{(26,27)}$ following the approach described by Higgins \& Green $^{(27)}$. The correlation coefficient $(0 \cdot 5)$ assumed in the derivation was similar to the average coefficient derived from a study in which variances were provided for baseline, treatment end, and change from baseline measures of fasting blood glucose and HOMA-IR; the correlation coefficient for fasting blood insulin derived from this study was $0 \cdot 7^{(28)}$. Hence, a sensitivity analysis assuming a correlation coefficient of 0.7 was conducted for fasting blood insulin.

A random-effects model was used to determine the mean and $95 \%$ CI of differences in changes from baseline between $100 \%$ juice and control groups. The approach described in DerSimonian \& Laird ${ }^{(29)}$ was used to conduct the randomeffects model. Stratified analyses by study characteristics were planned a priori to investigate sources of heterogeneity and univariate meta-regressions were conducted for further investigation. For each of the biomarkers of diabetes, analyses were conducted for type of fruit juice (apple, berry, blend, citrus, grape, pomegranate), type of control beverage (beverage matched for carbohydrate or sugar and/or energy, beverage without carbohydrate or sugar and/or energy, no beverage), volume of intervention beverage (as reported in the original studies for the meta-regression analysis, and categorised as $\leq 250 \mathrm{ml} / \mathrm{d},>250 \mathrm{ml} / \mathrm{d}$ in the stratified analysis), duration of

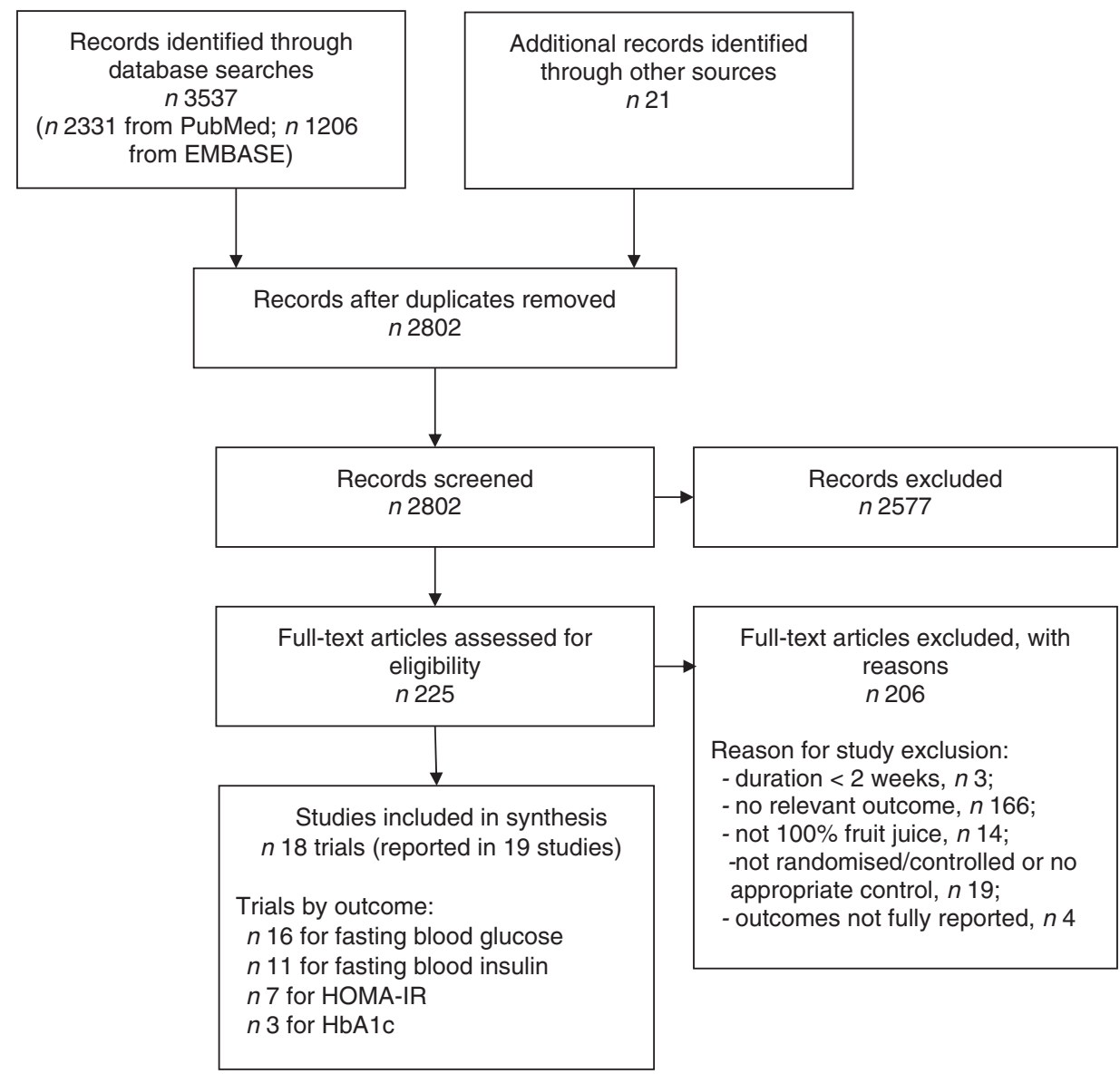

Fig. 1. Flow diagram of study selection process. HOMA-IR, homeostatic model assessment of insulin resistance; HbA1c, glycosylated Hb. 
Table 1. Characteristics of eighteen randomised controlled trials of $100 \%$ fruit juice included in analysis

\begin{tabular}{|c|c|c|c|c|c|c|c|c|c|c|c|}
\hline Reference & $\begin{array}{l}\text { Location: } \\
\text { continent } \\
\text { (country) }\end{array}$ & $\begin{array}{l}\text { Study population: health, } \\
\text { sex, mean age (years) } \pm \text { SD }\end{array}$ & Study design & $\begin{array}{l}\text { Mean baseline } \\
\text { BMI }\left(\mathrm{kg} / \mathrm{m}^{2}\right) \pm \mathrm{SD}\end{array}$ & $\begin{array}{l}\text { Subjects: } \\
\text { test/control } \\
(n)\end{array}$ & $\begin{array}{c}\text { Mean } \\
\text { baseline } \\
\text { glucose } \\
(\mathrm{mmol} / \mathrm{l})\end{array}$ & Duration* & $\begin{array}{l}\text { Juice test productt: } \\
\text { type }(\mathrm{ml} / \mathrm{d}) \text {, sugars } \\
(\mathrm{g} / \mathrm{d})\end{array}$ & $\begin{array}{l}\text { Control } \\
\text { product }\end{array}$ & $\begin{array}{l}\text { Outcome(s), } \\
\text { primary or } \\
\text { secondary }\end{array}$ & $\begin{array}{l}\text { Industry } \\
\text { fundingf }\end{array}$ \\
\hline $\begin{array}{l}\text { Banini et al. } \\
\qquad(2006)^{(35)}\end{array}$ & $\begin{array}{l}\text { North America } \\
\text { (USA) }\end{array}$ & $\begin{array}{l}\text { Healthy; M/F } \\
\text { Test: } 50 \pm 13 \\
\text { Control: } 56 \pm 7.5\end{array}$ & Parallel & $\begin{array}{l}\text { Test: } 29 \cdot 3 \pm 4 \cdot 0 \\
\text { Control: } 27 \cdot 5 \pm 5 \cdot 4\end{array}$ & $8 / 15$ & $<5.6$ & 4 weeks & $\begin{array}{l}\text { Grape } \\
\text { (muscadine) } \\
150, \text { about } 23 \\
\text { (estimated) }\end{array}$ & $\begin{array}{l}\text { No } \\
\text { beverage }\end{array}$ & $\begin{array}{l}\mathrm{FBG} / \mathrm{FBI} / \\
\mathrm{HbA} 1 \mathrm{c}, \mathrm{P}\end{array}$ & Yes \\
\hline $\begin{array}{l}\text { Cerdá et al. } \\
\qquad(2006)^{(20)}\end{array}$ & $\begin{array}{l}\text { Europe } \\
\text { (Spain) }\end{array}$ & $\begin{array}{l}\text { COPD; } M \\
\text { Test: } 60 \pm 10 \cdot 9 \\
\text { Control: } 63 \cdot 4 \pm 8.9\end{array}$ & Parallel & $\begin{array}{l}\text { Test: } 31 \cdot 4 \pm 4 \cdot 8 \\
\text { Control: } 30 \cdot 6 \pm 5 \cdot 8\end{array}$ & $15 / 15$ & $\geq 5.6$ & 5 weeks & $\begin{array}{l}\text { Pomegranate } \\
400, \text { about } 53 \\
\text { (estimated) }\end{array}$ & $\begin{array}{l}\text { Sugar-free } \\
\text { bev }\end{array}$ & FBG, S & No \\
\hline $\begin{array}{l}\text { Codoñer-Franch } \\
\text { et al. }(2010)^{(36)}\end{array}$ & $\begin{array}{l}\text { Europe } \\
\text { (Spain) }\end{array}$ & $\begin{array}{l}\text { Obese; } \mathrm{M} / \mathrm{F} \\
\text { Test: } 11 \cdot 8 \pm 2 \cdot 4 \\
\text { Control: } 12 \cdot 1 \pm 1 \cdot 9\end{array}$ & Parallel & $\begin{array}{l}\text { Test: } 29 \cdot 3 \pm 3 \cdot 5 \\
\text { Control: } 28 \cdot 7 \pm 4 \cdot 2\end{array}$ & $20 / 20$ & $<5.6$ & 4 weeks & $\begin{array}{l}\text { Mandarin } \\
500,53\end{array}$ & $\begin{array}{l}\text { No } \\
\text { beverage }\end{array}$ & $\begin{array}{l}\text { FBG/FBI/ } \\
\text { HOMA-IR, S }\end{array}$ & Yes \\
\hline $\begin{array}{l}\text { Dohadwala et al. } \\
\qquad(2010)^{(37)}\end{array}$ & $\begin{array}{l}\text { North America } \\
\text { (USA) }\end{array}$ & $\begin{array}{l}\text { HTN/pre-HTN; M/F } \\
\text { Test: } 41 \pm 13 \\
\text { Control: } 44 \pm 11\end{array}$ & Cross-over & $\begin{array}{l}\text { Test: } 28 \pm 3.8 \\
\text { Control: } 28 \pm 3.9\end{array}$ & $64 / 64$ & $<5.6$ & 8 weeks & $\begin{array}{l}\text { Grape (Concord) } \\
595 \S, 97\end{array}$ & Sugar bev & $\begin{array}{l}\text { FBG/FBI/ } \\
\text { HOMA-IR, S }\end{array}$ & Yes \\
\hline $\begin{array}{l}\text { González-Ortiz } \\
\text { et al. }(2011)^{(21)}\end{array}$ & $\begin{array}{l}\text { North America } \\
\text { (Mexico) }\end{array}$ & $\begin{array}{l}\text { Obese; F } \\
\text { Test: } 36 \cdot 3 \pm 8 \cdot 3 \\
\text { Control: } 38 \cdot 3 \pm 10 \cdot 4\end{array}$ & Parallel & $\begin{array}{l}\text { Test: } 35 \cdot 2 \pm 3 \cdot 1 \\
\text { Control: } 33 \cdot 8 \pm 4 \cdot 1\end{array}$ & $10 / 10$ & $<5.6$ & 1 month & $\begin{array}{l}\text { Pomegranate } \\
120, \text { about } 16 \\
\text { (estimated) }\end{array}$ & $\begin{array}{l}\text { Sugar-free } \\
\text { bev }\end{array}$ & $\begin{array}{l}\text { FBG/FBI/ } \\
\text { other, } \mathrm{P}\end{array}$ & No \\
\hline $\begin{array}{l}\text { Guo et al. } \\
\qquad(2014)^{(38)}\end{array}$ & Asia (China) & $\begin{array}{l}\text { NAFLD; M/F } \\
21 \cdot 2 \pm 1 \cdot 2\end{array}$ & Cross-over & $\begin{array}{l}\text { Test: } 25 \cdot 3 \pm 2 \cdot 2 \\
\text { Control: } 25 \cdot 6 \pm 2 \cdot 5\end{array}$ & $44 / 43$ & $<5.6$ & 4 weeks & $\begin{array}{l}\text { Bayberry } \\
500,46\end{array}$ & Sugar bev & FBG, S & No \\
\hline $\begin{array}{l}\text { Habauzit et al. } \\
\qquad(2015)^{(39)}\end{array}$ & $\begin{array}{l}\text { Europe } \\
\text { (France) }\end{array}$ & $\begin{array}{l}\text { Healthy; F } \\
57 \cdot 8 \pm 3 \cdot 7\end{array}$ & Cross-over & $25 \cdot 7 \pm 2 \cdot 3$ & $48 / 48$ & $<5.6$ & 6 months & $\begin{array}{l}\text { Grapefruit (white) } \\
340,27\end{array}$ & Sugar bev & $\begin{array}{l}\text { FBG/FBI/ } \\
\text { HOMA-IR, S }\end{array}$ & Yes \\
\hline $\begin{array}{l}\text { Hollis et al. } \\
\qquad(2009)^{(33)}\end{array}$ & $\begin{array}{l}\text { North America } \\
\text { (USA) }\end{array}$ & $\begin{array}{l}\text { Overweight; M/F } \\
\text { Test: } 22 \pm 4 \\
\text { Control: } 26 \pm 9\end{array}$ & Parallel & $\begin{array}{l}\text { Test: } 27 \cdot 0 \pm 1 \cdot 6 \\
\text { Control: } 27 \cdot 0 \pm 1 \cdot 5\end{array}$ & $25 / 26$ & $<5.6$ & 12 weeks & $\begin{array}{l}\text { Grape (Concord) } \\
480,82\end{array}$ & Sugar bev & FBG, S & Yes \\
\hline $\begin{array}{l}\text { Krikorian et al. } \\
\qquad(2012)^{(40)}\end{array}$ & $\begin{array}{l}\text { North America } \\
\text { (USA) }\end{array}$ & $\begin{array}{l}\mathrm{MCl} ; \mathrm{M} / \mathrm{F} \\
76 \cdot 9 \pm 6 \cdot 1\end{array}$ & Parallel & Not reported & $10 / 11$ & $\geq 5.6$ & 16 weeks & $\begin{array}{l}\text { Grape (Concord) } \\
532 \S \text {, about } 80 \\
\text { (estimated) }\end{array}$ & Sugar bev & FBG/FBI, S & Yes \\
\hline $\begin{array}{l}\text { Morand et al. } \\
\qquad(2011)^{(41)}\end{array}$ & $\begin{array}{l}\text { Europe } \\
\text { (France) }\end{array}$ & $\begin{array}{l}\text { Overweight; M } \\
56 \pm 4.8\end{array}$ & Cross-over & $27 \cdot 4 \pm 1 \cdot 4$ & $23 / 23$ & $<5.6$ & 4 weeks & $\begin{array}{l}\text { Orange } \\
500,45\end{array}$ & Sugar bev & FBG, FBI, S & Yes \\
\hline $\begin{array}{l}\text { Ravn-Haren et al. } \\
\qquad(2013)^{(34)}\end{array}$ & $\begin{array}{l}\text { Europe } \\
\text { (Denmark) }\end{array}$ & $\begin{array}{l}\text { Healthy; M/F } \\
36 \cdot 2 \pm 17.9\end{array}$ & Cross-over & $22 \cdot 3 \pm 2 \cdot 6$ & $23 / 23$ & $<5.6$ & 4 weeks & $\begin{array}{l}\text { Apple (clear) } \\
500,63\end{array}$ & $\begin{array}{l}\text { No } \\
\text { beverage }\end{array}$ & FBI, S & No \\
\hline $\begin{array}{l}\text { Shidfar et al. } \\
\qquad(2012)^{(22)}\end{array}$ & Asia (Iran) & $\begin{array}{l}\text { T2D; M } \\
54 \cdot 8 \pm 9 \cdot 1\end{array}$ & Parallel & $28 \cdot 8 \pm 3 \cdot 9$ & $29 / 29$ & $\geq 5.6$ & 12 weeks & $\begin{array}{l}\text { Cranberry } \\
240, \text { about } 31 \\
\text { (estimated) }\end{array}$ & $\begin{array}{l}\text { Sugar-free } \\
\text { bev }\end{array}$ & FBG, P & No \\
\hline $\begin{array}{l}\text { Silver et al. } \\
\qquad(2011)^{(42)}\end{array}$ & $\begin{array}{l}\text { North America } \\
\text { (USA) }\end{array}$ & $\begin{array}{l}\text { Obese; } \mathrm{M} / \mathrm{F} \\
\text { Test: } 39 \cdot 8 \pm 8 \cdot 4 \\
\text { Control: } 38 \cdot 7 \pm 8 \cdot 8\end{array}$ & Parallel & $\begin{array}{l}\text { Test: } 35 \cdot 2 \pm 3 \cdot 1 \\
\text { Control: } 35 \cdot 7 \pm 3 \cdot 5\end{array}$ & $22 / 23$ & $<5.6$ & 12 weeks & $\begin{array}{l}\text { Grapefruit (white) } \\
\text { about } 360 \\
\text { (estimated), } \\
\text { about } 28 \\
\text { (estimated) }\end{array}$ & $\begin{array}{l}\text { Sugar-free } \\
\text { bev }\end{array}$ & $\begin{array}{l}\text { FBG/FBI/ } \\
\text { HOMA-IR, S }\end{array}$ & Yes \\
\hline $\begin{array}{l}\text { Simpson } \\
\quad \text { et al.2016 }\end{array}$ & Europe (UK) & $\begin{array}{l}\text { Overweight/obese, } \\
\text { hypercholesterolaemic; M } \\
\text { Test: } 48 \cdot 3 \pm 3 \cdot 9 \\
\text { Control: } 48 \cdot 9 \pm 4 \cdot 3\end{array}$ & Parallel & $\begin{array}{l}\text { Test: } 29 \cdot 9 \pm 2 \cdot 3 \\
\text { Control: } 29 \cdot 3 \pm 1 \cdot 7\end{array}$ & $18 / 18$ & $<5 \cdot 6$ & 12 weeks & $\begin{array}{l}\text { Orange } \\
250,22\end{array}$ & Sugar bev & HOMA-IR, S & Yes \\
\hline $\begin{array}{l}\text { Sohrab et al. } \\
\qquad(2014, \\
2015)^{(28,32)}\end{array}$ & Asia (Iran) & $\begin{array}{l}\text { T2D; M/F } \\
\text { Test: } 55 \pm 6 \cdot 7 \\
\text { Control: } 56 \cdot 9 \pm 6 \cdot 8\end{array}$ & Parallel & $\begin{array}{l}\text { Test: } 29 \cdot 4 \pm 3 \cdot 9 \\
\text { Control: } 28 \cdot 6 \pm 4 \cdot 2\end{array}$ & 22/22 & $\geq 5.6$ & 12 weeks & $\begin{array}{l}\text { Pomegranate } \\
250,24\end{array}$ & Sugar bev & $\begin{array}{l}\text { FBG/FBI/ } \\
\text { HOMA-IR/ } \\
\text { HbA1c, S }\end{array}$ & No \\
\hline
\end{tabular}




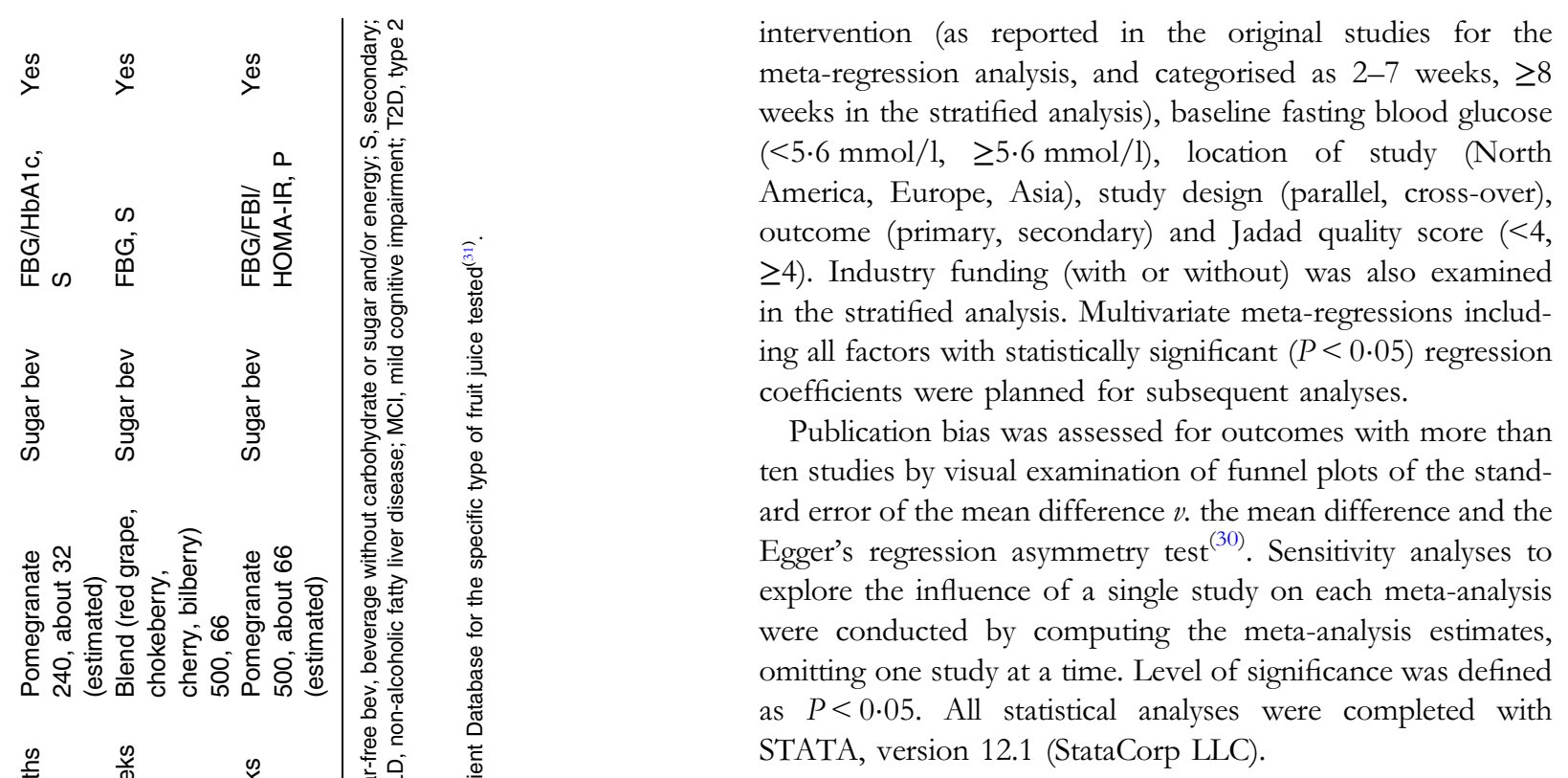

Results

\section{Literature search, study characteristics}

A total of eighteen RCT of $100 \%$ fruit juice were eligible for inclusion in the present review (Fig. 1). Characteristics of the eighteen RCT of $100 \%$ fruit juice and measures of glucose control or insulin sensitivity included in the meta-analysis are presented in Table $1^{(31)}$. Two publications provided relevant outcomes from the same clinical trial and results from both publications were captured for the analysis ${ }^{(28,32)}$. In two of the identified studies, results of two comparisons of potential interest were presented ${ }^{(33,34)}$, though in order to avoid doublecounting of studies, one comparison from each was selected for inclusion in the meta-analysis ${ }^{(33)}$. In a parallel-design study of the effects of Concord grape juice, the energy-matched control beverage ( $v$. a no-beverage control) was selected for the control group ${ }^{(33)}$. In a cross-over study providing clear or cloudy apple juice within two of the five study arms ${ }^{(34)}$, clear apple juice was selected for the test group as this type of juice is assumed to be more commonly consumed.

Sixteen of the eighteen included trials reported data for fasting blood glucose ${ }^{(20-23,28,32,33,35-43)}$, eleven reported fasting blood insulin ${ }^{(21,28,34-37,39-43)}$, seven reported HOMA-IR ${ }^{(28,36,}$ $37,39,42-44)$ and three reported $\mathrm{HbA1} \mathrm{c}^{(28,35,45)}$. Duration of supplementation ranged from 2 weeks to 6 months, with the majority of studies providing the intervention for a period of 8 weeks or more. The studies were predominantly conducted in Europe $(n 8)$ or North America $(n 7)$, with the remaining three studies conducted in Asia ( $n$ 3).

All but five studies included a test and control arm; four studies included three arms ${ }^{(23,33,41,42)}$ and one study included five arms ${ }^{(34)}$. Although all studies were controlled, the type of control beverage provided varied across studies. Across the eighteen studies, twelve indicated some level of industry funding including financial support and/or test products.

Six studies had a Jadad score of $\geq 4^{(23,28,32,33,37,39,45)}$, while the remaining trials (twelve of eighteen) had a Jadad score of 
Table 2. Jadad scores of study quality and major sources of potential bias by study

\begin{tabular}{|c|c|c|c|c|c|c|c|}
\hline \multirow{2}{*}{ Reference } & \multicolumn{2}{|c|}{ Randomised } & \multicolumn{2}{|c|}{ Doubled-blind } & \multicolumn{2}{|c|}{ Withdrawals and dropouts } & \multirow{2}{*}{ Major sources of potential bias } \\
\hline & $\begin{array}{l}\text { Yes/ } \\
\text { no* }\end{array}$ & Method $\dagger$ & $\begin{array}{l}\text { Yes/ } \\
\text { no* }\end{array}$ & Method $\dagger$ & Description & $\begin{array}{l}\text { Cumulative } \\
\text { Jadad score }\end{array}$ & \\
\hline Banini et al. (2006) $)^{(35)}$ & 1 & 0 & 0 & 0 & 0 & 1 & $\begin{array}{l}\text { Unclear risk of selection bias, attrition bias; } \\
\text { high risk of performance bias }\end{array}$ \\
\hline Cerdá et al. (2006) & 1 & 0 & 1 & 1 & 0 & 3 & Unclear risk of selection bias, attrition bias \\
\hline Codoñer-Franch et al. $(2010)^{(36)}$ & 1 & 0 & 0 & 0 & 0 & 1 & $\begin{array}{l}\text { Unclear risk of selection bias, attrition bias; } \\
\text { high risk of performance bias }\end{array}$ \\
\hline Dohadwala et al. $(2010)^{(37)}$ & 1 & 1 & 1 & 1 & 1 & 5 & $\begin{array}{l}\text { High risk of attrition bias }-23 \% \text { of subjects } \\
\text { withdrew from the study }\end{array}$ \\
\hline González-Ortiz et al. (2011) $)^{(21)}$ & 1 & 0 & 1 & 0 & 1 & 3 & $\begin{array}{l}\text { Unclear risk of selection bias, } \\
\text { performance bias }\end{array}$ \\
\hline Guo et al. $(2014)^{(38)}$ & 1 & 0 & 1 & 0 & 1 & 3 & $\begin{array}{l}\text { Unclear risk of selection bias, } \\
\text { performance bias }\end{array}$ \\
\hline Habauzit et al. (2015) ${ }^{(39)}$ & 1 & 0 & 1 & 1 & 1 & 4 & Unclear risk of selection bias \\
\hline Hollis et al. (2009) ${ }^{(33)}$ & 1 & 0 & 1 & 1 & 1 & 4 & Unclear risk of selection bias \\
\hline Krikorian et al. $(2012)^{(40)}$ & 1 & 0 & 1 & 1 & 0 & 3 & Unclear risk of selection bias, attrition bias \\
\hline Morand et al. $(2011)^{(41)}$ & 1 & 1 & 0 & 0 & 1 & 3 & High risk of performance bias \\
\hline Ravn-Haren et al. $(2013)^{(34)}$ & 1 & 0 & 0 & 0 & 1 & 2 & $\begin{array}{l}\text { Unclear risk of selection bias; high risk of } \\
\text { performance bias; high risk of } \\
\text { attrition bias - } 32 \% \text { of enrolled subjects } \\
\text { dropped out before completing } \\
\text { all treatments; unclear risk of study design } \\
\text { bias - unspecified washout period } \\
\text { between treatments }\end{array}$ \\
\hline Shidfar et al. (2012) & 1 & 0 & 1 & 0 & 1 & 3 & $\begin{array}{l}\text { Unclear risk of selection bias, } \\
\text { performance bias }\end{array}$ \\
\hline Silver et al. $(2011)^{(42)}$ & 1 & 1 & 0 & 0 & 1 & 3 & $\begin{array}{l}\text { High risk of performance bias; high risk of } \\
\text { attrition bias }-20 \% \text { of study subjects } \\
\text { dropped out between study weeks } 6 \text { and } 9\end{array}$ \\
\hline Simpson et al. $(2016)^{(44)}$ & 1 & 1 & 0 & 0 & 1 & 3 & High risk of performance bias \\
\hline Sohrab et al. $(2014,2015)^{(28,32)}$ & 1 & 0 & 1 & 1 & 1 & 4 & Unclear risk of selection bias \\
\hline Sumner et al. $(2005)^{(45)}$ & 1 & 1 & 1 & 1 & 1 & 5 & - \\
\hline Tjelle et al. (2015) & 1 & 0 & 1 & 1 & 1 & 4 & Unclear risk of selection bias \\
\hline Tsang et al. $(2012)^{(43)}$ & 1 & 0 & 0 & 0 & 1 & 2 & $\begin{array}{l}\text { Unclear risk of selection bias; high risk of } \\
\text { performance bias }\end{array}$ \\
\hline
\end{tabular}

*Yes, 1; no, 0.

† Appropriate, 1; inappropriate, -1 ; not specified, 0.

$<4$. As shown in Table 2, each study was identified by the investigators as a randomised study, though only five provided the methods of random sequence generation. Eleven of the studies were reported to be double-blind, and eight of these detailed a method regarded as appropriate within the Jadad criteria. The remaining eight studies were open label or single blind. Descriptions of study withdrawals, including both the number and reason, were provided in fourteen of the eighteen studies. No studies described inappropriate randomisation or double-blinding methods. High risk for attrition bias was identified in three studies and a cross-over study with an unspecified washout period between treatments presented unclear risk for bias.

\section{Effect of $100 \%$ fruit juice on fasting blood glucose}

In the meta-analysis of fasting blood glucose data reported in sixteen RCT, consumption of $100 \%$ fruit juice had no significant effect on fasting blood glucose compared with the control treatment $(-0.13(95 \% \mathrm{CI}-0.28,0.01) \mathrm{mmol} / \mathrm{l}$; $P=0.07$ ) (Fig. 2); there was moderate to high heterogeneity among the studies $\left(P<0 \cdot 01, I^{2}=70 \cdot 6\right)$. Stratified analyses (Table 3) used to evaluate potential sources of heterogeneity resulted in mean difference estimates ranging from $-0 \cdot 70$ to $0 \cdot 20$. Associations that were statistically significant in stratified analyses included an intervention of $2-7$ weeks $(-0 \cdot 20$ (95\% CI $\left.-0.38,-0.08) \mathrm{mmol} / \mathrm{l} ; P=0.03, I^{2}=57.0\right)$, and studies with a Jadad score of $<4(-0.23(95 \%$ CI -0.43 , $-0.03) \mathrm{mmol} / \mathrm{l} ; P=0.03, I^{2}=74.8$ ); in both of these stratified analyses, fasting blood glucose was lowered by consumption of $100 \%$ fruit juice compared with the control group. The only factor with a statistically significant regression coefficient in the univariate meta-regressions was study location; therefore no multivariate meta-regression analyses were conducted.

\section{Effect of $100 \%$ fruit juice on fasting blood insulin}

Compared with the control treatment, consumption of $100 \%$ fruit juice had no significant effect on fasting blood insulin $(-0.24(95 \% \mathrm{CI}-3.54,3.05) \mathrm{pmol} / \mathrm{l} ; P=0.89)$ with no heterogeneity $\left(P=0.52, I^{2}=0\right)$ in the eleven RCT included in the analysis (Fig. 3). Stratified analyses of the effects of $100 \%$ fruit juice on fasting blood insulin resulted in mean difference estimates ranging from -8.50 to $11 \cdot 6$, none of which was statistically significant (Table 4). 


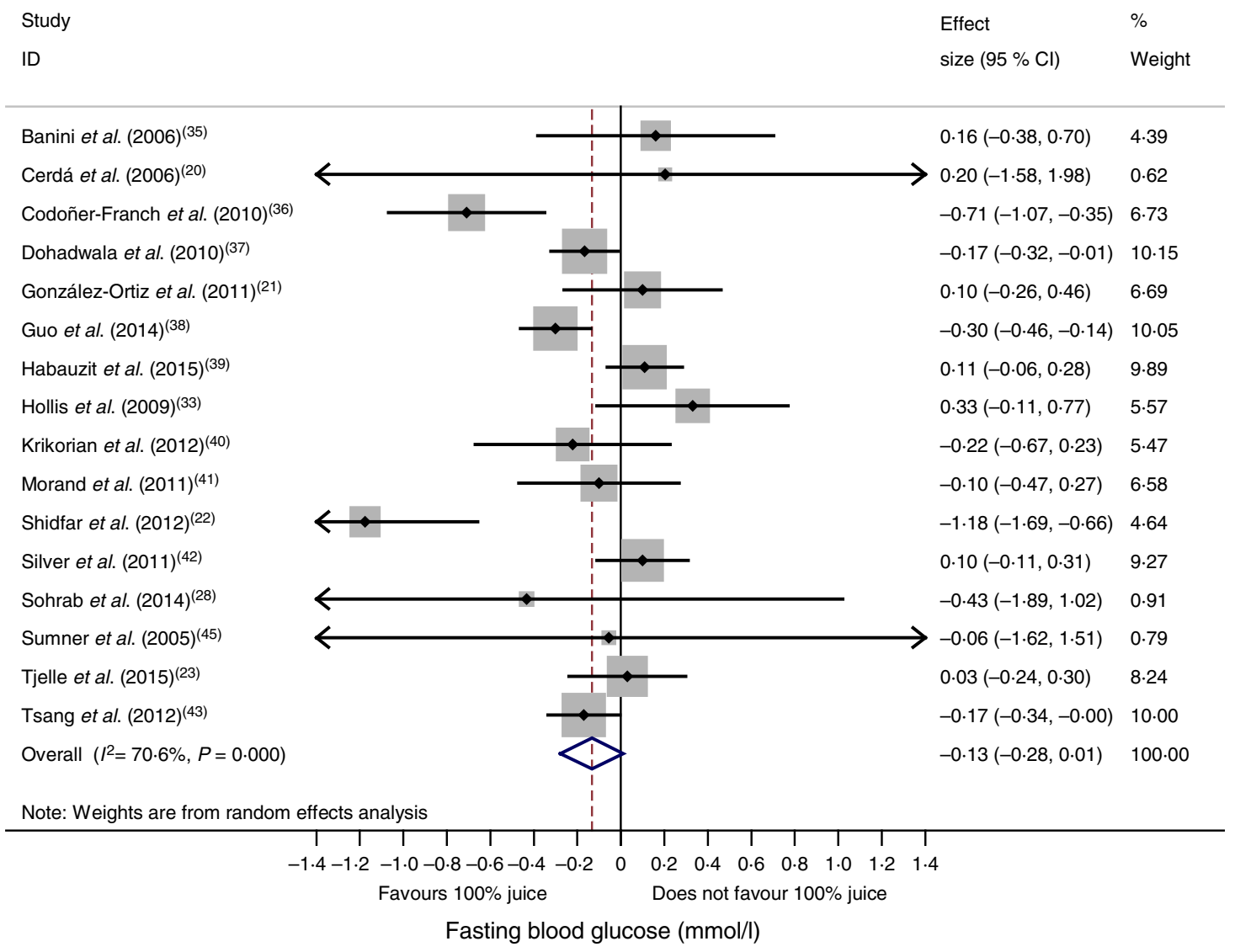

Fig. 2. Meta-analysis of the effects of $100 \%$ fruit juice on fasting blood glucose. Square values represent the mean difference of fasting blood glucose values (mmol/l) based on a random-effects model; $95 \%$ confidence intervals are represented by horizontal lines. Square size is proportional to the weight of each study. The diamond represents the pooled estimate of mean differences $(P=0.07)$.

\section{Effect of $100 \%$ fruit juice on insulin resistance}

The effect of $100 \%$ fruit juice on HOMA-IR was not significant $(-0.22(95 \% \mathrm{CI}-0.50,0.06) ; P=0.13)$ with moderate to high heterogeneity $\left(P<0 \cdot 01, I^{2}=73.9\right)$ (Fig. 4). Stratified analyses resulted in mean difference estimates ranging from -1.60 to 0.50 (Table 5). In stratified analyses, HOMA-IR was significantly lower in the $100 \%$ fruit juice groups compared with the control group in studies in which pomegranate juice was consumed $(-0.37$ (95\% CI $-0.57,-0 \cdot 18) ; P<$ $\left.0 \cdot 005, I^{2}=0\right)$ or intervention duration was $2-7$ weeks $(-0 \cdot 41$ $\left.(95 \% \mathrm{CI}-0.59,-0.23) ; P<0.005, I^{2}=0\right)$. In the univariate meta-regressions, only volume of juice intervention showed a statistically significant inverse association with change in HOMA-IR (regression coefficient $=-0 \cdot 002 ; P=0 \cdot 01$ ).

\section{Effect of $100 \%$ fruit juice on glycosylated $\mathrm{Hb}$}

The effect of $100 \%$ fruit juice on HbA1c was not significant $(-0.001(95 \% \mathrm{CI}-0.38,0.38) \% ; P>0.99)$ with low heterogeneity $\left(P<0 \cdot 01, I^{2}=22 \cdot 3\right)$ (Fig. 5). Stratified analyses resulted in mean difference estimates ranging from -0.11 to 0.60 (Table 6). No statistically significant associations were observed in the stratified analyses or univariate meta-regressions.

\section{Publication bias}

The potential for publication bias was investigated through visual inspection of funnel plots for analyses with a sufficient number of studies, namely fasting blood glucose and fasting blood insulin. Visual inspection of funnel plots for fasting blood glucose showed that all but three studies ${ }^{(22,36,38)}$ fell inside the funnel. These three studies had relatively smaller mean difference estimates indicative of statistically significant beneficial effects of the intervention beverages. Sensitivity analyses in which each study was removed from the analysis individually or all three simultaneously resulted in a mean difference that was still negative and not significantly different from zero (data not shown), thus suggesting no publication bias. Results from the Egger's test supported this conclusion for both fasting blood glucose and insulin (Fig. 6; $P=0.80$ and $0 \cdot 38$, respectively).

\section{Sensitivity analysis}

Sensitivity analyses that excluded individual RCT resulted in estimates similar to values derived from all studies, although some mean differences became statistically significant. In the case of fasting blood glucose, omission of either of three studies ${ }^{(33,39,42)}$ resulted in overall mean difference estimates that were statistically significant and indicative of a beneficial effect of $100 \%$ fruit juice consumption (mean difference of $-0 \cdot 16$; $95 \% \mathrm{CI}-0 \cdot 31,-0 \cdot 005)$. The effects of $100 \%$ fruit juice on fasting blood insulin or HOMA-IR were not found to be sensitive to any particular study included in the meta-analysis. The sensitivity analysis conducted for fasting blood insulin assuming 
Table 3. Stratified analyses of effects of $100 \%$ fruit juice on fasting blood glucose (FBG)

\begin{tabular}{|c|c|c|c|c|c|c|c|c|c|}
\hline \multirow[b]{2}{*}{ Parameter } & \multirow[b]{2}{*}{ Studies $(n)$} & \multirow[b]{2}{*}{ Net change } & \multirow[b]{2}{*}{$95 \% \mathrm{Cl}$} & \multirow[b]{2}{*}{ Overall $P$} & \multicolumn{2}{|c|}{$\begin{array}{c}\text { Test of } \\
\text { heterogeneity }\end{array}$} & \multicolumn{3}{|c|}{$\begin{array}{l}\text { Unadjusted (univariate) } \\
\text { meta-regression }\end{array}$} \\
\hline & & & & & $P$ & $P(\%)$ & $\mathrm{RC}$ & SE & $P$ \\
\hline All studies & 16 & -0.13 & $-0.28,0.01$ & 0.07 & $<0.005$ & $70 \cdot 6$ & & & \\
\hline \multicolumn{10}{|l|}{ Fruit juice type } \\
\hline Apple & - & - & - & - & - & - & - & - & - \\
\hline Berry & 2 & -0.70 & $-1 \cdot 56,0 \cdot 15$ & 0.11 & $<0.005$ & $90 \cdot 0$ & -0.56 & 0.32 & 0.11 \\
\hline Blend & 1 & 0.03 & $-0.24,0.30$ & 0.83 & - & - & 0.10 & 0.39 & 0.81 \\
\hline Citrus & 4 & -0.12 & $-0.43,0.19$ & 0.45 & $<0.005$ & 83.1 & -0.06 & 0.27 & 0.84 \\
\hline Grape & 4 & -0.03 & $-0.28,0.22$ & 0.83 & 0.14 & $45 \cdot 9$ & 0.07 & 0.28 & 0.82 \\
\hline Pomegranate & 5 & -0.12 & $-0.27,0.03$ & 0.10 & 0.72 & 0 & Reference & - & - \\
\hline \multicolumn{10}{|l|}{ Control group } \\
\hline Sugar bev & 10 & -0.09 & $-0.21,0.03$ & 0.14 & 0.04 & $49 \cdot 6$ & 0.26 & 0.29 & 0.39 \\
\hline Sugar-free bev & 4 & -0.24 & $-0.84,0.36$ & 0.43 & $<0.005$ & $85 \cdot 6$ & 0.13 & 0.34 & 0.71 \\
\hline No beverage & 2 & -0.30 & $-1.15,0.55$ & 0.49 & 0.01 & 85.5 & Reference & - & - \\
\hline Volume of juice & & & & & & & $<0.005$ & $<0.005$ & 0.75 \\
\hline$\leq 250 \mathrm{ml} / \mathrm{d}$ & 5 & -0.29 & $-0.93,0.36$ & 0.38 & $<0.005$ & $77 \cdot 9$ & - & - & - \\
\hline$>250 \mathrm{ml} / \mathrm{d}$ & 11 & -0.11 & $-0.25,0.03$ & $0 \cdot 13$ & $<0.005$ & $69 \cdot 1$ & - & - & - \\
\hline Duration & & & & & & & 0.01 & 0.01 & 0.44 \\
\hline 2-7 weeks & 7 & -0.20 & $-0.38,-0.02$ & 0.03 & 0.03 & $57 \cdot 0$ & - & - & -- \\
\hline$\geq 8$ weeks & 9 & -0.09 & $-0.30,0.12$ & 0.39 & $<0.005$ & $72 \cdot 9$ & - & - & - \\
\hline \multicolumn{10}{|l|}{ Baseline FBG } \\
\hline$<5.6 \mathrm{mmol} / /$ & 11 & -0.08 & $-0.21,0.06$ & 0.28 & $<0.005$ & $70 \cdot 7$ & Reference & - & - \\
\hline$\geq 5.6 \mathrm{mmol} / \mathrm{l}$ & 5 & -0.51 & $-1.10,0.09$ & 0.10 & 0.07 & $54 \cdot 3$ & -0.49 & 0.23 & 0.06 \\
\hline \multicolumn{10}{|l|}{ Location } \\
\hline Asia & 3 & -0.65 & $-1.36,0.05$ & 0.07 & 0.01 & $80 \cdot 0$ & Reference & - & - \\
\hline Europe & 6 & -0.14 & $-0.36,0.09$ & 0.24 & $<0.005$ & $72 \cdot 8$ & 0.45 & 0.24 & 0.08 \\
\hline North America & 7 & 0.01 & $-0.15,0.16$ & 0.94 & 0.19 & 31.0 & 0.62 & 0.24 & 0.02 \\
\hline \multicolumn{10}{|l|}{ Outcome } \\
\hline Primary & 4 & -0.25 & $-0.70,0.20$ & 0.27 & $<0.005$ & 83.4 & Reference & - & - \\
\hline Secondary & 12 & -0.10 & $-0.26,0.05$ & 0.20 & $<0.005$ & $65 \cdot 6$ & 0.14 & 0.21 & 0.53 \\
\hline \multicolumn{10}{|l|}{ Study design } \\
\hline Cross-over & 5 & -0.13 & $-0.28,0.02$ & 0.08 & 0.02 & $66 \cdot 9$ & 0.02 & 0.19 & 0.91 \\
\hline Parallel & 11 & -0.15 & $-0.43,0.12$ & 0.27 & $<0.005$ & 73.9 & Reference & - & - \\
\hline \multicolumn{10}{|l|}{ Jadad score } \\
\hline$<4$ & 10 & -0.23 & $-0.43,-0.03$ & 0.03 & $<0.005$ & 74.8 & Reference & - & - \\
\hline$\geq 4$ & 6 & 0.02 & $-0.15,0.18$ & 0.86 & 0.13 & $40 \cdot 9$ & 0.26 & 0.18 & 0.17 \\
\hline \multicolumn{10}{|l|}{ Study funding } \\
\hline Industry support & 11 & -0.07 & $-0.21,0.07$ & 0.34 & $<0.005$ & 62.5 & 0.30 & 0.20 & 0.17 \\
\hline No industry support & 5 & -0.38 & $-0.84,0.08$ & 0.11 & $<0.005$ & $75 \cdot 1$ & Reference & - & - \\
\hline
\end{tabular}

RC, regression coefficient; sugar bev, beverage matched for carbohydrate or sugar and/or energy; sugar-free bev, beverage with non-energy-containing or no added sweetener.

a correlation coefficient of 0.7 in the derivation of the pooled variance for cross-over studies showed no significant effect of $100 \%$ fruit juice on fasting blood insulin (results not shown).

\section{Discussion}

The present systematic review and meta-analysis provides a comprehensive, quantitative assessment of the relationship between $100 \%$ fruit juice and measures of glycaemic control. Results from this meta-analysis of eighteen RCT show no significant effect of $100 \%$ fruit juice on fasting blood glucose, fasting blood insulin, insulin resistance as evaluated by HOMA-IR or HbA1c. Additionally, results of stratified analyses confirm the lack of consistent associations between $100 \%$ fruit juice consumption and these markers for diabetes. The absence of any clear adverse or beneficial effect of $100 \%$ fruit juice on markers of diabetes in the present meta-analysis of available RCT suggests a largely neutral role of $100 \%$ fruit juice on glucose-insulin homeostasis.

The findings of the present meta-analysis are generally consistent with a 2014 meta-analysis by Wang et al. ${ }^{(12)}$. Overall, seven studies were included in both the previous and the present meta-analysis ${ }^{(20,21,33,35,37,41,45)}$. The eleven additional trials included in the present analysis reflect recent additions to the literature as well as studies not captured by Wang et al. ${ }^{(12)}$. As in the present analysis, no significant effect on glycaemic control measured by fasting glucose, fasting insulin or $\mathrm{HbA} 1 \mathrm{c}$ was reported in the meta-analysis of studies identified as $100 \%$ fruit juice by Wang et al. ${ }^{(12)}$. In contrast to the present analysis in which no effect of $100 \%$ fruit juice on HOMA-IR was found, a significant increase in HOMA-IR was reported by Wang et al. ${ }^{(12)}$ based on data from three trials, only one of which was considered eligible for the present meta-analysis ${ }^{(45)}$. The other two HOMA-IR values in the meta-analysis by Wang et al. ${ }^{(12)}$ include a value from a study not meeting our inclusion criteria $^{(16)}$, and a value attributed to the trial by Sumner et al..$^{(45)}$ which was neither reported in that paper nor noted as sourced from the study authors. The value attributed to Sumner accounted for $78 \%$ of the weighted mean HOMA-IR in the meta-analysis by Wang et al. ${ }^{(12)}$, and therefore largely explains the difference between the previous and present analyses. Findings from the present meta-analysis of RCT on markers 


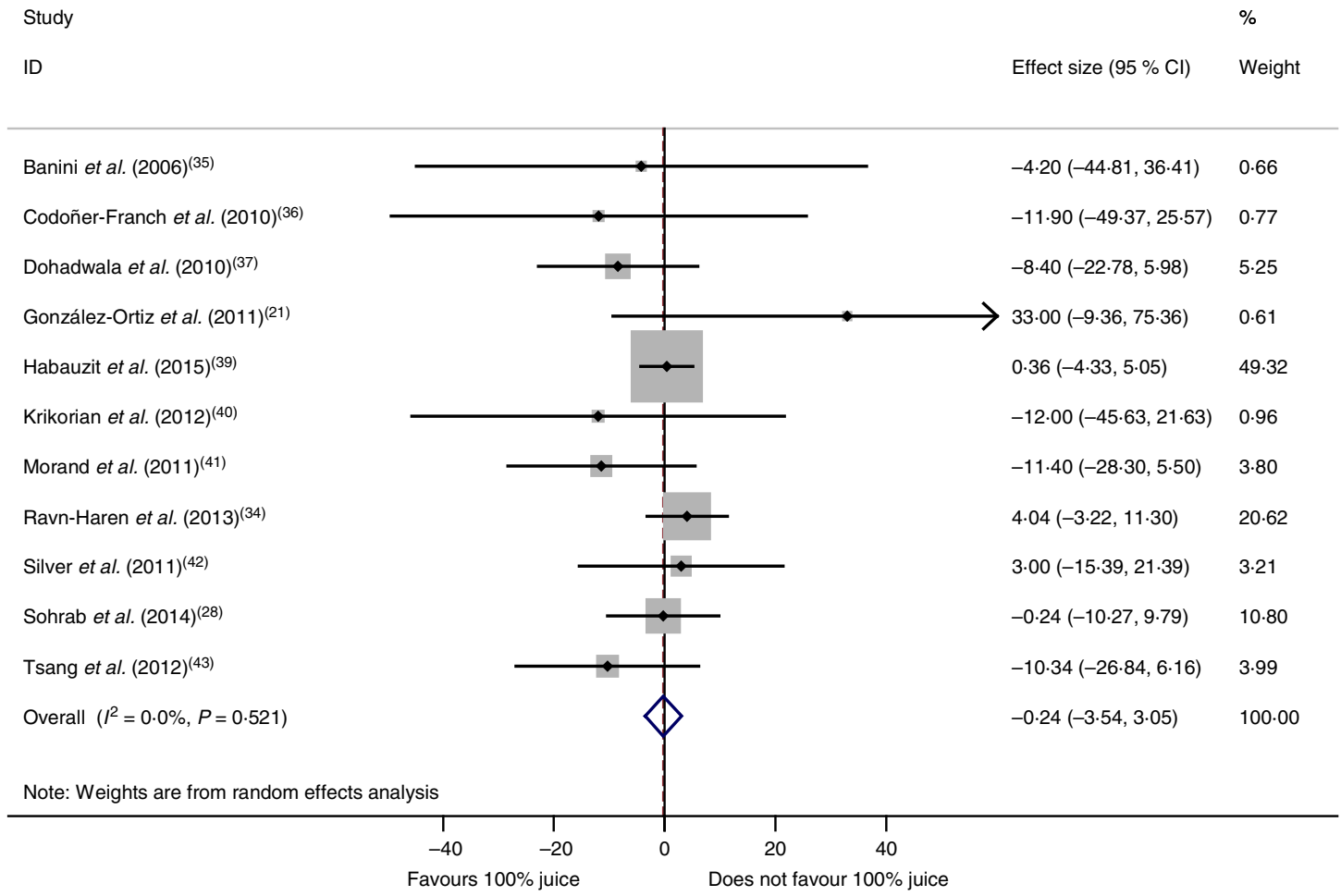

Fasting blood insulin (pmol/l)

Fig. 3. Meta-analysis of the effects of $100 \%$ fruit juice on fasting blood insulin. Square values represent the mean difference of fasting blood insulin values (pmol/l) based on a random-effects model; $95 \%$ confidence intervals are represented by horizontal lines. Square size is proportional to the weight of each study. The diamond represents the pooled estimate of mean differences $(P=0.89)$.

for diabetes are also consistent with findings from a meta-analysis of prospective cohorts showing that consumption of $100 \%$ fruit juice is not associated with increased risk of T2D ${ }^{(46)}$ and findings from a more recent meta-analysis of cohorts in which diabetes was clinically verified ${ }^{(11)}$.

Stratified analyses were conducted as part of the present meta-analysis to investigate specific conditions that may adversely or beneficially affect glucose-insulin homeostasis. The stratifications included parameters to differentiate among the juice intervention, study population and study characteristics. Consistent with the primary findings, results from the stratified analyses showed no significant effect of $100 \%$ fruit juice on fasting blood insulin and $\mathrm{HbA1c}$, though results of both analyses, and in particular HbA1c, were limited by the small number of studies. Stratified analyses of fasting blood glucose showed a significantly greater reduction from baseline with $100 \%$ fruit juice compared with the control in trials with an intervention duration of 2-7 weeks and trials with a Jadad score $<4$. The significant effect observed in shorter studies could reflect higher compliance by study participants over a shorter study intervention. However, a cross-tabulation of the studies with fasting blood glucose data by these two factors reveals that all studies with a shorter duration of intervention (2-7 weeks) also had a Jadad score $<4$, which is an indicator of a lower methodological quality trial. As detailed in the review of Jadad scores by studies (Table 2), many of the RCT suggesting a beneficial effect of $100 \%$ fruit juice on fasting blood glucose had one or more major sources of potential bias, and in particular high or unclear performance bias. Findings in the stratified analyses therefore provide some though limited support for a beneficial effect of fruit juice on fasting blood glucose. Stratified analyses of HOMA-IR also showed a significantly greater reduction from baseline with $100 \%$ fruit juice compared with the control in trials with an intervention duration of 2-7 weeks, and additionally in trials with pomegranate juice. The significance of these findings also is limited, as each analysis was based on data from only two studies and did not notably reduce heterogeneity. The inverse association of volume of $100 \%$ fruit juice with HOMA-IR identified in univariate meta-regressions also is an indicator of potentially beneficial effects of $100 \%$ fruit juice, albeit very small as evidenced by the relatively small regression coefficient.

A variety of juices was provided as test beverages across the studies and the types and concentrations of some bioactives in fruit juice vary across fruit juice type. For example, pomegranate juice is a unique source of ellagitannins, including punicalagins $^{(47)}$. Among citrus juices, grapefruit juice is a concentrated source of naringin while the primary flavonoid in orange juice is hesperidin ${ }^{(48,49)}$. Cranberries are a source of polyphenols including procyanidins, anthocyanins, quercetin and myricitrin ${ }^{(50)}$, the primary anthocyanins in many grape juices are glucosides of cyanidin or delphinidin ${ }^{(49,51)}$, and apple juice is a source of quercetin ${ }^{(49,51)}$. The amount of fruit juice consumed during the dietary interventions was also highly variable, with juice intake of approximately two cups or more (480 to $595 \mathrm{ml}$ ) per $\mathrm{d}$ in nine of the interventions and one cup or less in six studies $(<250 \mathrm{ml})$. The amount of sugars provided by the juices ranged from 22 to $97 \mathrm{~g}$. The 
Table 4. Stratified analyses of effects of $100 \%$ fruit juice on fasting blood insulin

\begin{tabular}{|c|c|c|c|c|c|c|c|c|c|}
\hline \multirow[b]{2}{*}{ Parameter } & \multirow[b]{2}{*}{ Studies $(n)$} & \multirow[b]{2}{*}{ Net change } & \multirow[b]{2}{*}{$95 \% \mathrm{Cl}$} & \multirow{2}{*}{$\begin{array}{l}\text { Overall } \\
P\end{array}$} & \multicolumn{2}{|c|}{$\begin{array}{c}\text { Test of } \\
\text { heterogeneity }\end{array}$} & \multicolumn{3}{|c|}{$\begin{array}{l}\text { Unadjusted (univariate) } \\
\text { meta-regression }\end{array}$} \\
\hline & & & & & $P$ & $R(\%)$ & $\mathrm{RC}$ & $\mathrm{SE}$ & $P$ \\
\hline All studies & 11 & -0.24 & $-3.54,3.05$ & 0.89 & 0.52 & 0 & & & \\
\hline \multicolumn{10}{|l|}{ Fruit juice type } \\
\hline Apple & 1 & 4.04 & $-3 \cdot 22,11 \cdot 3$ & 0.28 & . & - & 5.59 & $5 \cdot 66$ & 0.36 \\
\hline Berry & - & - & - & - & - & - & - & - & - \\
\hline Blend & - & - & - & - & - & - & - & - & - \\
\hline Citrus & 4 & -0.44 & $-4.80,3.92$ & 0.84 & 0.53 & 0 & $1 \cdot 11$ & 4.83 & 0.83 \\
\hline Grape & 3 & -8.50 & $-21.07,4.07$ & 0.19 & 0.96 & 0 & -6.95 & $7 \cdot 71$ & 0.40 \\
\hline Pomegranate & 3 & -0.72 & $-14.90,13.46$ & 0.92 & 0.16 & $46 \cdot 1$ & Reference & - & - \\
\hline \multicolumn{10}{|l|}{ Control group } \\
\hline Sugar bev & 6 & -1.69 & $-5.52,2 \cdot 14$ & 0.39 & 0.50 & 0 & -5.52 & 4.78 & 0.28 \\
\hline Sugar-free bev & 2 & 11.68 & $-14.98,38.34$ & 0.39 & 0.20 & 38.3 & 4.95 & 9.73 & 0.63 \\
\hline No beverage & 3 & 3.24 & $-3.78,10.25$ & 0.37 & 0.67 & 0 & Reference & - & - \\
\hline Volume of juice & & & & & & & -0.02 & 0.02 & 0.26 \\
\hline$\leq 250 \mathrm{ml} / \mathrm{d}$ & 3 & $2 \cdot 66$ & $-11.29,16.61$ & 0.71 & 0.32 & 13.5 & - & - & - \\
\hline$>250 \mathrm{ml} / \mathrm{d}$ & 8 & -0.44 & $-3.96,3.07$ & 0.81 & 0.46 & 0 & - & - & - \\
\hline Duration & & & & & & & 0.09 & 0.24 & 0.73 \\
\hline 2-7 weeks & 6 & $-2 \cdot 13$ & $-11 \cdot 60,7 \cdot 35$ & 0.66 & 0.21 & $30 \cdot 6$ & - & - & - \\
\hline$\geq 8$ weeks & 5 & -0.44 & $-4.40,3.51$ & 0.83 & 0.76 & 0 & - & - & - \\
\hline \multicolumn{10}{|l|}{ Baseline FBG } \\
\hline$<5.6 \mathrm{mmol} / \mathrm{l}$ & 9 & -0.41 & $-4.48,3.66$ & 0.84 & 0.37 & 7.4 & Reference & - & - \\
\hline$\geq 5.6 \mathrm{mmol} / \mathrm{l}$ & 2 & -1.20 & $-10 \cdot 81,8 \cdot 41$ & 0.81 & 0.51 & 0 & -1.09 & $5 \cdot 24$ & 0.84 \\
\hline \multicolumn{10}{|l|}{ Location } \\
\hline Asia & 1 & -0.24 & $-10.27,9.79$ & 0.96 & - & - & Reference & - & - \\
\hline Europe & 5 & -0.43 & $-5 \cdot 24,4 \cdot 38$ & 0.86 & 0.30 & $17 \cdot 6$ & 0.33 & $5 \cdot 74$ & 0.96 \\
\hline North America & 5 & $-2 \cdot 70$ & $-12 \cdot 78,7 \cdot 39$ & 0.60 & 0.41 & 0 & -2.45 & 7.63 & 0.76 \\
\hline \multicolumn{10}{|l|}{ Outcome } \\
\hline Primary & 3 & 0.73 & $-23 \cdot 20,24 \cdot 65$ & 0.95 & 0.17 & $42 \cdot 7$ & Reference & - & - \\
\hline Secondary & 8 & 0 & $-3.39,3.39$ & 1.00 & 0.63 & 0 & 4.58 & 7.54 & 0.56 \\
\hline \multicolumn{10}{|l|}{ Study design } \\
\hline Cross-over & 5 & -1.41 & $-6.58,3.76$ & 0.59 & 0.22 & $30 \cdot 4$ & -0.54 & 4.50 & 0.91 \\
\hline Parallel & 6 & 0.21 & $-7 \cdot 78,8 \cdot 20$ & 0.96 & 0.65 & 0 & Reference & - & - \\
\hline \multicolumn{10}{|l|}{ Jadad score } \\
\hline$<4$ & 8 & -0.89 & $-7 \cdot 60,5 \cdot 81$ & 0.79 & 0.35 & $10 \cdot 2$ & Reference & - & - \\
\hline$\geq 4$ & 3 & -0.44 & $-4.52,3.63$ & 0.83 & 0.53 & 0 & -0.48 & 3.86 & 0.90 \\
\hline \multicolumn{10}{|l|}{ Study funding } \\
\hline Industry support & 8 & -1.84 & $-5 \cdot 83,2 \cdot 16$ & 0.37 & 0.68 & 0 & $-6 \cdot 13$ & $4 \cdot 31$ & 0.19 \\
\hline No industry support & 3 & $3 \cdot 20$ & $-3 \cdot 78,10 \cdot 19$ & 0.37 & 0.30 & $16 \cdot 8$ & Reference & - & - \\
\hline
\end{tabular}

RC, regression coefficient; sugar bev, beverage matched for carbohydrate or sugar and/or energy; sugar-free bev, beverage with non-energy-containing or no added sweetener; FBG, fasting blood glucose.

' $100 \%$ fruit juice' category therefore represents a heterogeneous food group and differences in the type and composition of fruit juices may be important when considering the physiological effects of fruit juice, including effects on glycaemic control and insulin sensitivity. Stratified analyses, however, showed no clear differences across categorisations and heterogeneity was not notably reduced.

The RCT of $100 \%$ fruit juices identified in the present review also used a variety of control products, including energycontaining beverages matched for sugar or carbohydrate content, sugar-free beverages containing non-energy-containing sweeteners or only water, and, in some studies, no beverage. Peluso \& Palmery ${ }^{(52)}$ have noted that selection of an appropriate placebo in studies of the postprandial response to fruit juice is critical, with energy and sugar-matched beverages (including proportions of glucose and fructose) providing an appropriate control to assess the effects of bioactives in juice, and a water beverage providing an appropriate control to assess the effects of juice as a whole ${ }^{(52)}$. Stratified analyses of fasting blood glucose by these control group comparisons did not result in significant effects, suggesting that neither the non-sugar juice components nor the juice itself had an effect on fasting blood glucose in the clinical trials.

The effects of $100 \%$ fruit juice on measures of glucose control or insulin sensitivity varied little across study population characteristics including baseline fasting blood glucose levels. Body weight status of study participants is another important characteristic as overweight and obesity are recognised risk factors for the development of T2D due to decreased sensitivity of non-adipose tissue to insulin ${ }^{(2)}$. In all but one of the studies with reported BMI data ${ }^{(34)}$, mean BMI exceeded $25 \mathrm{~kg} / \mathrm{m}^{2}$, indicating that the study populations were generally overweight or obese individuals. The available reported data on body weight or BMI indicate no differences in change between the juice intervention and control groups. In addition to weight status, the study populations also represented a variety of health states including healthy, diabetic, hypertensive/prehypertensive, hypercholesterolaemic, and adults with various other conditions. While many of these conditions are common co-morbidities of overweight and obesity, it is difficult to 


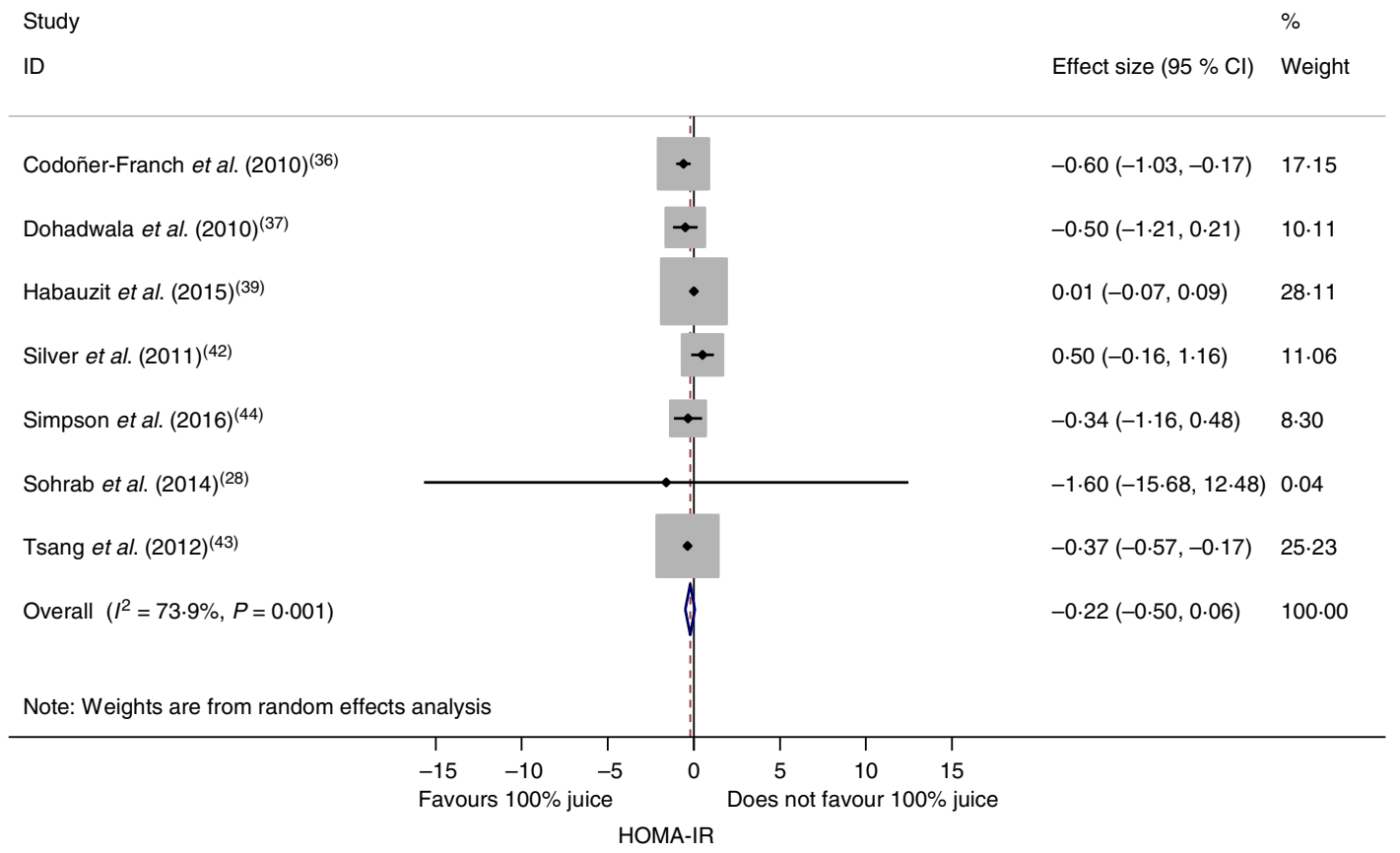

Fig. 4. Meta-analysis of the effects of $100 \%$ fruit juice on the homeostatic model assessment of insulin resistance (HOMA-IR). Square values represent the mean difference of the HOMA-IR index based on a random-effects model; $95 \%$ confidence intervals are represented by horizontal lines. Square size is proportional to the weight of each study. The diamond represents the pooled estimate of mean differences $(P=0.13)$.

delineate their independent role in the relationship between $100 \%$ fruit juice consumption and diabetes risk.

Many methods are used to assess bias in RCT when conducting a meta-analysis, including the Jadad criteria ${ }^{(53)}$. Based on the Jadad criteria, which reflect randomisation, double blinding, and recording of withdrawals and dropouts ${ }^{(19)}$, the majority of studies in this meta-analysis had an unclear risk of selection bias due to absence of a description of the random sequence generation. A relatively high proportion of studies were non-double-blind (seven of eighteen) which points to a high risk of performance bias. Regarding attrition bias, the majority of studies (fourteen of eighteen) provided information on participant disposition throughout the study and the data largely indicate low risk of bias, though attrition was relatively high $(20-32 \%)$ in three studies ${ }^{(34,37,42)}$ and the remaining studies have unknown or potentially high risk for this source of bias. Other potential sources of bias not captured in the Jadad criteria but noted upon review of the studies include unknown or potentially high bias due to an unspecified washout period between interventions ${ }^{(34)}$.

Despite concerns that $100 \%$ fruit juice may have adverse effects on glycaemic control, primarily as a result of sugars in these beverages, results from this analysis of RCT do not support a conclusion that $100 \%$ fruit juice adversely affects glucose-insulin homeostasis. The results largely indicate no effect on glycaemic control. Some stratified analyses suggest the possibility of a beneficial effect of $100 \%$ fruit juice on fasting blood glucose and HOMA-IR, though the evidence is inconclusive based on limitations of the available data. A mechanism by which $100 \%$ fruit juice may have a favourable effect on measures of glycaemic control is not clearly known, though some evidence, largely from in vitro and animal studies, indicates that polyphenols may favourably affect glucose- insulin homeostasis through a variety of mechanisms including inhibition of glucose absorption, stimulation of insulin secretion from the pancreas and change in glucose release from the liver, activation of insulin receptors and glucose uptake by cells, and modulation of cell signalling pathways and gene expression ${ }^{(10)}$. Further research is needed to understand these effects.

A strength of the present meta-analysis is the large number of randomised, controlled clinical trials identified for inclusion in the quantitative analysis. The broad though focused search strategy identified studies in which glucose metabolism outcomes were primary outcomes as well as studies in which the measures were collected as secondary outcomes or routine monitoring during the clinical trials. The large number of identified studies allowed for stratified analyses by similar characteristics of the intervention, study population, and overall study design to further explore effects of $100 \%$ fruit juice on diabetes biomarkers. However, sample sizes in many stratified analyses were relatively small, and many analyses may result in detection of spurious associations, therefore these findings must be interpreted with caution.

Although the total number of identified studies was relatively large, variability among some parameters of study interventions, populations, and overall study design are limitations of this analysis and must be considered when interpreting the findings. The included studies reflect a diverse range of juice interventions (both type of juice and amount consumed), intervention durations, variable dietary restrictions throughout the intervention period (and typically no restrictions on consumption of other types of $100 \%$ fruit juice), study populations with a range of health conditions, and studies with potential for some bias. Variability in these factors and potentially other factors not considered in the analysis contribute to the observed heterogeneity among studies, thus making it difficult to conclusively interpret the findings. 
Table 5. Stratified analyses of effects of $100 \%$ fruit juice on the homeostatic model assessment of insulin resistance

\begin{tabular}{|c|c|c|c|c|c|c|c|c|c|}
\hline \multirow[b]{2}{*}{ Parameter } & \multirow[b]{2}{*}{ Studies $(n)$} & \multirow[b]{2}{*}{ Net change } & \multirow[b]{2}{*}{$95 \% \mathrm{Cl}$} & \multirow{2}{*}{$\begin{array}{l}\text { Overall } \\
P\end{array}$} & \multicolumn{2}{|c|}{$\begin{array}{c}\text { Test of } \\
\text { heterogeneity }\end{array}$} & \multicolumn{3}{|c|}{$\begin{array}{l}\text { Unadjusted (univariate) } \\
\text { meta-regression }\end{array}$} \\
\hline & & & & & $P$ & $R(\%)$ & $\mathrm{RC}$ & SE & $P$ \\
\hline All studies & 7 & -0.22 & $-0.5,0.06$ & 0.13 & $<0.005$ & 73.9 & & & \\
\hline \multicolumn{10}{|l|}{ Fruit juice type } \\
\hline Apple & - & - & - & - & - & - & - & - & - \\
\hline Berry & - & - & - & - & - & - & - & - & - \\
\hline Blend & - & - & - & - & - & - & - & - & - \\
\hline Citrus & 4 & -0.11 & $-0.52,0.29$ & 0.58 & 0.02 & $70 \cdot 8$ & 0.26 & 0.44 & 0.58 \\
\hline Grape & 1 & -0.50 & $-1 \cdot 21,0.21$ & 0.17 & - & - & -0.12 & 0.64 & 0.86 \\
\hline Pomegranate & 2 & -0.37 & $-0.57,-0.18$ & 0.00 & 0.86 & 0 & Reference & - & - \\
\hline \multicolumn{10}{|l|}{ Control group } \\
\hline Sugar bev & 5 & -0.23 & $-0.53,0.07$ & 0.14 & 0.01 & 71.9 & 0.38 & 0.34 & 0.33 \\
\hline Sugar-free bev & 1 & 0.50 & $-0 \cdot 16,1 \cdot 16$ & 0.14 & - & - & $1 \cdot 10$ & 0.51 & 0.10 \\
\hline No beverage & 1 & -0.60 & $-1.03,-0.17$ & 0.01 & - & - & Reference & - & - \\
\hline Volume of juice & & & & & & & $<0.005$ & $<0.005$ & 0.01 \\
\hline$\leq 250 \mathrm{ml} / \mathrm{d}$ & 2 & -0.34 & $-1.17,0.48$ & 0.41 & 0.86 & 0 & - & - & - \\
\hline$>250 \mathrm{ml} / \mathrm{d}$ & 5 & -0.21 & $-0.51,0.10$ & 0.19 & $<0.005$ & $82 \cdot 2$ & - & - & - \\
\hline Duration & & & & & & & 0.02 & 0.01 & 0.08 \\
\hline 2-7 weeks & 2 & -0.41 & $-0.59,-0.23$ & 0.00 & 0.35 & 0 & - & - & - \\
\hline$\geq 8$ weeks & 5 & -0.01 & $-0.25,0.23$ & 0.92 & 0.31 & $16 \cdot 9$ & & - & - \\
\hline \multicolumn{10}{|l|}{ Baseline FBG } \\
\hline$<5.6 \mathrm{mmol} / \mathrm{l}$ & 6 & -0.22 & $-0.50,0.07$ & 0.14 & $<0.005$ & $78 \cdot 2$ & Reference & - & - \\
\hline$\geq 5.6 \mathrm{mmol} / \mathrm{l}$ & 1 & -1.60 & $-15 \cdot 68,12 \cdot 48$ & 0.82 & - & - & -1.38 & $7 \cdot 36$ & 0.86 \\
\hline \multicolumn{10}{|l|}{ Location } \\
\hline Asia & 1 & -1.60 & $-15 \cdot 68,12 \cdot 48$ & 0.82 & - & - & Reference & - & - \\
\hline Europe & 4 & -0.28 & $-0.61,0.04$ & 0.08 & $<0.005$ & 83.9 & 1.31 & $7 \cdot 31$ & 0.87 \\
\hline North America & 2 & 0.01 & $-0.97,0.99$ & 0.99 & 0.04 & 75.4 & 1.62 & $7 \cdot 31$ & 0.84 \\
\hline \multicolumn{10}{|l|}{ Outcome } \\
\hline Primary & 1 & -0.37 & $-0.57,-0.18$ & $<0.005$ & - & - & Reference & - & - \\
\hline Secondary & 6 & -0.17 & $-0.52,0.18$ & 0.34 & 0.03 & $58 \cdot 8$ & 0.20 & 0.39 & 0.64 \\
\hline \multicolumn{10}{|l|}{ Study design } \\
\hline Cross-over & 3 & -0.22 & $-0.56,0.12$ & 0.20 & $<0.005$ & 85.4 & -0.05 & 0.35 & 0.90 \\
\hline Parallel & 4 & -0.18 & $-0.83,0.48$ & 0.60 & 0.06 & $59 \cdot 9$ & Reference & - & - \\
\hline \multicolumn{10}{|l|}{ Jadad score } \\
\hline$<4$ & 4 & -0.27 & $-0.64,0.10$ & 0.16 & 0.05 & $60 \cdot 8$ & Reference & - & - \\
\hline$\geq 4$ & 3 & 0 & $-0.08,0.09$ & 0.95 & 0.37 & 0 & 0.11 & 0.34 & 0.75 \\
\hline \multicolumn{10}{|l|}{ Study funding } \\
\hline Industry support & 6 & -0.22 & $-0.50,0.07$ & 0.14 & $<0.005$ & $78 \cdot 2$ & 1.38 & $7 \cdot 36$ & 0.86 \\
\hline No industry support & 1 & -1.60 & $-15 \cdot 68,12 \cdot 48$ & 0.82 & - & - & Reference & - & - \\
\hline
\end{tabular}

RC, regression coefficient; sugar bev, beverage matched for carbohydrate or sugar and/or energy; sugar-free bev, beverage with non-energy-containing or no added sweetener; FBG, fasting blood glucose.

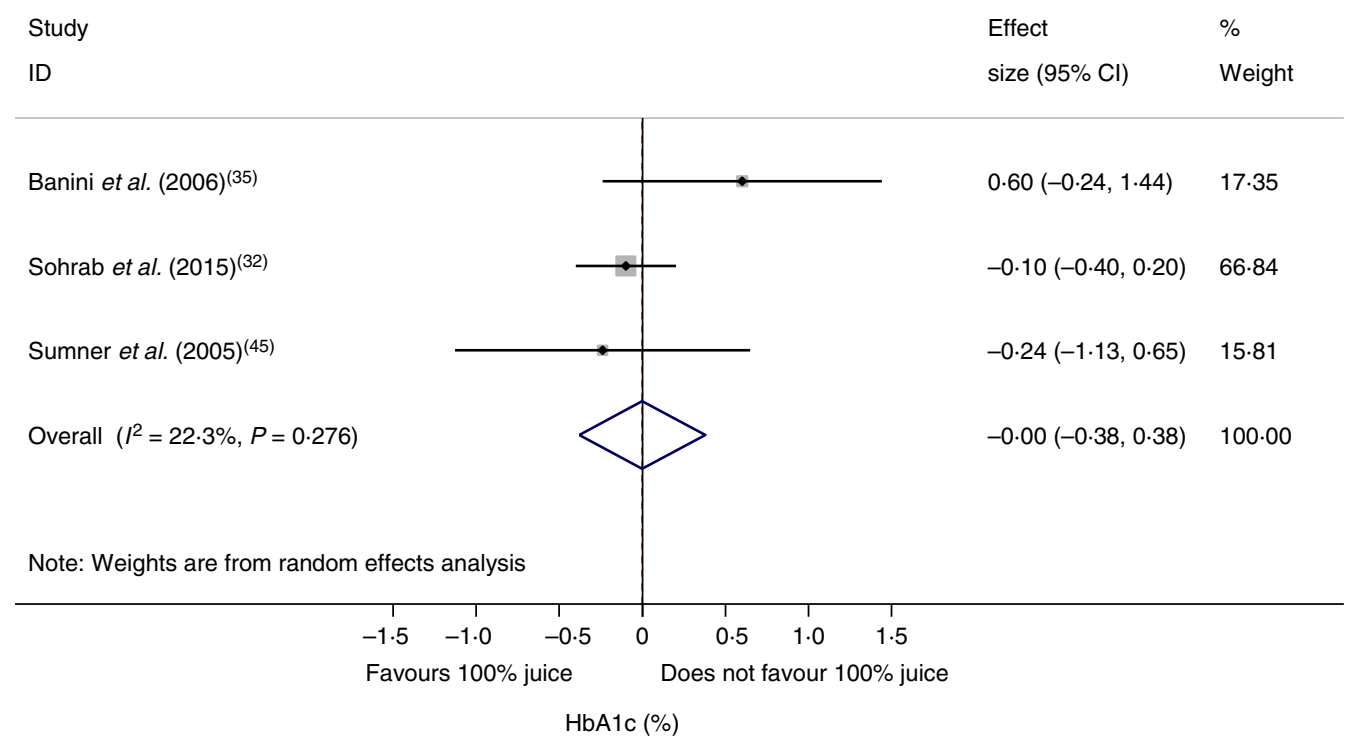

Fig. 5. Meta-analysis of the effects of $100 \%$ fruit juice on glycosylated $\mathrm{Hb}(\mathrm{HbA1c}$; \%). Square values represent the mean difference of $\mathrm{HbA1c}$ values based on a random-effects model; $95 \%$ confidence intervals are represented by horizontal lines. Square size is proportional to the weight of each study. The diamond represents the pooled estimate of mean differences $(P=1.00)$. 

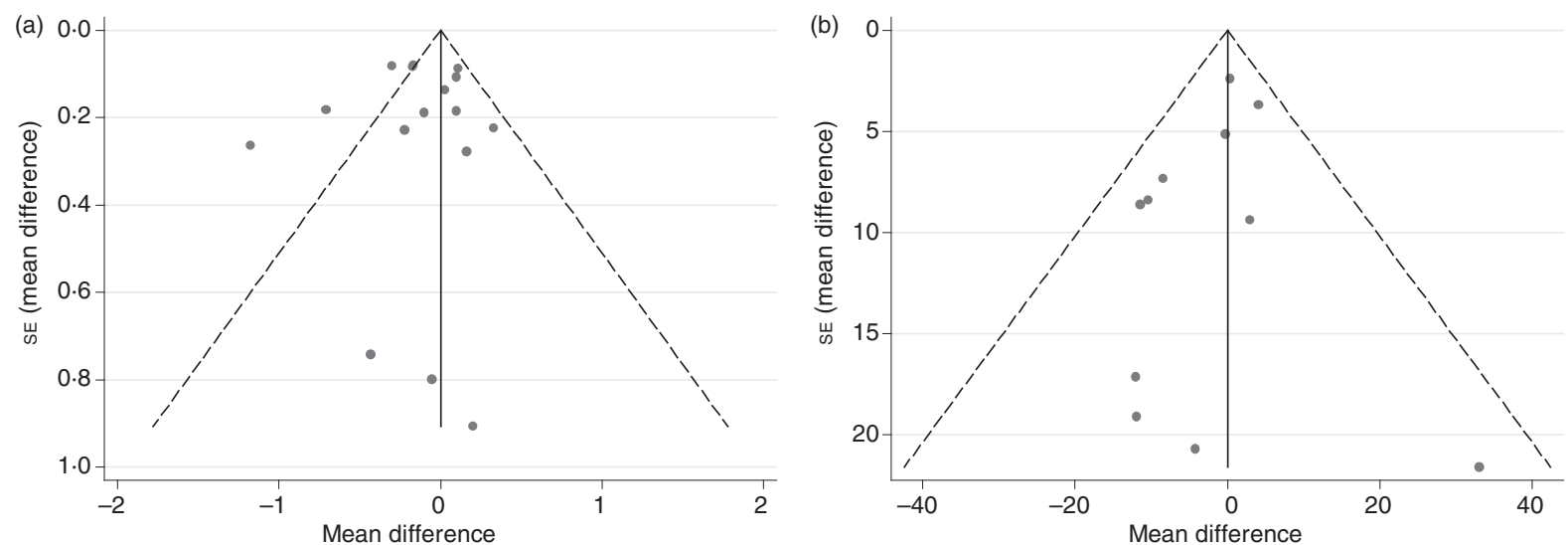

Fig. 6. Funnel plots with pseudo $95 \%$ confidence limits for detection of publication bias among randomised controlled trials examining fasting blood glucose (a) and fasting blood insulin (b). For fasting blood glucose, $P$ value for Egger's test $=0 \cdot 80$. For fasting blood insulin, $P$ value for Egger's test $=0.38$.

\section{Conclusion}

In conclusion, the available RCT indicate that repeated intake of $100 \%$ fruit juice does not have a significant effect on glycaemic control or measures of insulin resistance. These findings from RCT of markers for diabetes are consistent with findings from some observational studies suggesting that consumption of $100 \%$ fruit juice is neutral regarding

Table 6. Stratified analyses of effects of $100 \%$ fruit juice on glycosylated $\mathrm{Hb}(\%)$

\begin{tabular}{|c|c|c|c|c|c|c|c|c|c|}
\hline \multirow[b]{2}{*}{ Parameter } & \multirow[b]{2}{*}{ Studies $(n)$} & \multirow[b]{2}{*}{ Net change } & \multirow[b]{2}{*}{$95 \% \mathrm{Cl}$} & \multirow{2}{*}{$\begin{array}{l}\text { Overall } \\
P\end{array}$} & \multicolumn{2}{|c|}{$\begin{array}{c}\text { Test of } \\
\text { heterogeneity }\end{array}$} & \multicolumn{3}{|c|}{$\begin{array}{c}\text { Unadjusted (univariate) } \\
\text { meta-regression }\end{array}$} \\
\hline & & & & & $P$ & $P(\%)$ & $\mathrm{RC}$ & SE & $P$ \\
\hline All studies & 3 & -0.001 & $-0.38,0.38$ & 1.00 & 0.28 & $22 \cdot 3$ & - & - & - \\
\hline \multicolumn{10}{|l|}{ Fruit juice type } \\
\hline Apple & - & - & - & - & - & - & - & - & - \\
\hline Berry & - & - & - & - & - & - & - & - & - \\
\hline Blend & - & - & - & - & - & - & - & - & - \\
\hline Citrus & - & - & - & - & - & - & - & - & - \\
\hline Grape & 1 & 0.60 & $-0.24,1.44$ & 0.16 & - & - & 0.71 & 0.45 & 0.36 \\
\hline Pomegranate & 2 & -0.11 & $-0.40,0.17$ & 0.43 & 0.77 & 0 & Reference & - & - \\
\hline \multicolumn{10}{|l|}{ Control group } \\
\hline Sugar bev & 2 & -0.11 & $-0.40,0.17$ & 0.43 & 0.77 & 0 & -0.71 & 0.45 & 0.36 \\
\hline Sugar-free bev & - & - & - & - & - & - & - & - & - \\
\hline No beverage & 1 & 0.60 & $-0.24,1.44$ & 0.16 & - & - & Reference & - & - \\
\hline Volume of juice & & & & & & & -0.01 & 0.01 & 0.37 \\
\hline$\leq 250 \mathrm{ml} / \mathrm{d}$ & 3 & 0 & $-0.38,0.38$ & 1.00 & 0.28 & $22 \cdot 3$ & - & - & - \\
\hline$>250 \mathrm{ml} / \mathrm{d}$ & - & - & - & - & - & - & & & \\
\hline Duration & & & & & & & -0.09 & 0.06 & 0.36 \\
\hline 2-7 weeks & 1 & 0.60 & $-0.24,1.44$ & 0.16 & - & - & - & - & - \\
\hline$\geq 8$ weeks & 2 & -0.11 & $-0.40,0.17$ & 0.43 & 0.77 & 0 & - & - & - \\
\hline \multicolumn{10}{|l|}{ Baseline FBG } \\
\hline$<5.6 \mathrm{mmol} / \mathrm{l}$ & 1 & 0.60 & $-0.24,1.44$ & 0.16 & - & - & Reference & - & - \\
\hline$\geq 5.6 \mathrm{mmol} / \mathrm{l}$ & 2 & -0.11 & $-0.40,0.17$ & 0.43 & 0.77 & 0 & -0.71 & 0.45 & 0.36 \\
\hline \multicolumn{10}{|l|}{ Location } \\
\hline Asia & 1 & -0.10 & $-0.40,0.20$ & 0.52 & - & - & Reference & - & - \\
\hline Europe & - & - & - & - & - & - & - & - & - \\
\hline North America & 2 & 0.19 & $-0.63,1.02$ & 0.65 & 0.18 & $44 \cdot 8$ & 0.29 & 0.60 & 0.71 \\
\hline \multicolumn{10}{|l|}{ Outcome } \\
\hline Primary & 1 & 0.60 & $-0.24,1.44$ & 0.16 & - & - & Reference & - & - \\
\hline Secondary & 2 & -0.11 & $-0.40,0.17$ & 0.43 & 0.77 & 0 & -0.71 & 0.45 & 0.36 \\
\hline \multicolumn{10}{|l|}{ Study design } \\
\hline Cross-over & - & - & - & - & - & - & - & - & - \\
\hline Parallel & 3 & 0 & $-0.38,0.38$ & 1.00 & 0.28 & $22 \cdot 3$ & Reference & - & - \\
\hline \multicolumn{10}{|l|}{ Jadad score } \\
\hline$<4$ & 1 & 0.60 & $-0.24,1.44$ & 0.16 & - & - & Reference & - & - \\
\hline$\geq 4$ & 2 & -0.11 & $-0.40,0.17$ & 0.43 & 0.77 & 0 & -0.71 & 0.45 & 0.36 \\
\hline \multicolumn{10}{|l|}{ Study funding } \\
\hline Industry support & 2 & 0.19 & $-0.63,1.02$ & 0.65 & 0.18 & $44 \cdot 8$ & 0.29 & 0.60 & 0.71 \\
\hline No industry support & 1 & -0.10 & $-0.40,0.20$ & 0.52 & - & - & Reference & - & - \\
\hline
\end{tabular}

$\mathrm{RC}$, regression coefficient; sugar bev, beverage matched for carbohydrate or sugar and/or energy; sugar-free bev, beverage with non-energy-containing or no added sweetener; FBG, fasting blood glucose. 
risk of T2D. Results from stratified analyses and univariate meta-regressions also largely showed no significant associations between $100 \%$ fruit juice and these measures of glucose control. High-quality studies of glucose-insulin homeostasis measures monitored in well-defined and controlled populations are needed to further clarify the effects of $100 \%$ fruit juice on diabetes risk as evaluated by these biomarkers. Such research focused on commonly consumed juices served in moderate daily portions reflective of prudent dietary guidance would provide important information to further our understanding of the role of $100 \%$ fruit juice on glycaemic control.

\section{Acknowledgements}

The authors thank Xiaoyu Bi for her assistance in completing some statistical analyses and organising data output.

This work was supported by the Juice Products Association.

All authors were employees of Exponent, Inc. at the time of work on this analysis. The Juice Products Association is a client of Exponent, Inc.

M. M. M., E. C. B. and L. M. B. designed the study. M. M. M. and E. C. B. completed the literature searches and M. M. M., E. C. B. and K. A. B. completed the data extraction. L. M. B. oversaw all statistical analyses. M. M. M., E. C. B., K. A. B. and L. M. B. contributed to interpretation of the findings. M. M. M. drafted the manuscript. All authors read, critically reviewed, edited and approved the final manuscript. The Juice Products Association developed the research question though had no role in the study design, data collection and analysis, interpretation of the data, or preparation of the manuscript.

The study sponsor reviewed an early draft of the manuscript and provided minor editorial suggestions for consideration by the authors who retained the authority to accept or reject them.

\section{References}

1. Rolic G (2016) WHO global report on diabetes: a summary. Int J Non-Commun Dis 1, 3-8.

2. American Diabetes Association (2016) Classification and diagnosis of diabetes. Sec. 2. In Standards of Medical Care in Diabetes-2016. Diabetes Care 39, Suppl. 1, S13-S22.

3. Mozaffarian D (2016) Dietary and policy priorities for cardiovascular disease, diabetes, and obesity: a comprehensive review. Circulation 133, 187-225.

4. Li BW, Andrews KG \& Pehrsson PR (2002) Individual sugars, soluble, and insoluble dietary fiber contents of 70 high consumption foods. J Food Comp Anal 15, 715-723.

5. Liu RH (2013) Health-promoting components of fruits and vegetables in the diet. Adv Nutr 4, 384s-392s.

6. Rampersaud GC (2007) A comparison of nutrient density scores for 100\% fruit juices. J Food Sci 72, S261-S266.

7. United States Department of Health and Human Services \& United States Department of Agriculture (2015) Dietary Guidelines for Americans 2015-2020, 8th edition. http://health.gov/dietaryguidelines/2015/guidelines/ (accessed November 2017).

8. Atkinson FS, Foster-Powell K \& Brand-Miller JC (2008) International tables of glycemic index and glycemic load values: 2008. Diabetes Care 31, 2281-2283.

9. Augustin LS, Kendall CW, Jenkins DJ, et al. (2015) Glycemic index, glycemic load and glycemic response: an International Scientific Consensus Summit from the International Carbohydrate Quality Consortium (ICQC). Nutr Metab Cardiovasc Dis 25, 795-815.
10. Hanhineva K, Torronen R, Bondia-Pons I, et al. (2010) Impact of dietary polyphenols on carbohydrate metabolism. Int J Mol Sci 11, $1365-1402$

11. Imamura F, O'Connor L, Ye Z, et al. (2015) Consumption of sugar sweetened beverages, artificially sweetened beverages, and fruit juice and incidence of type 2 diabetes: systematic review, meta-analysis, and estimation of population attributable fraction. BMJ 351, h3576.

12. Wang B, Liu K, Mi M, et al. (2014) Effect of fruit juice on glucose control and insulin sensitivity in adults: a meta-analysis of 12 randomized controlled trials. PLOS ONE 9, e95323.

13. Basu A, Fu DX, Wilkinson M, et al. (2010) Strawberries decrease atherosclerotic markers in subjects with metabolic syndrome. Nutr Res 30, 462-469.

14. Basu A, Du M, Leyva MJ, et al. (2010) Blueberries decrease cardiovascular risk factors in obese men and women with metabolic syndrome. J Nutr 140, 1582-1587.

15. Basu A, Betts NM, Ortiz J, et al. (2011) Low-energy cranberry juice decreases lipid oxidation and increases plasma antioxidant capacity in women with metabolic syndrome. Nutr Res 31, 190-196.

16. Dohadwala MM, Holbrook M, Hamburg NM, et al. (2011) Effects of cranberry juice consumption on vascular function in patients with coronary artery disease. Am J Clin Nutr 93, 934-940.

17. Reshef N, Hayari Y, Goren C, et al. (2005) Antihypertensive effect of sweetie fruit in patients with stage I hypertension. Am J Hypertens 18, 1360-1363.

18. Moher D, Aliberati A, Tetzlaff J, et al. (2009) Preferred Reporting Items for Systematic Reviews and Meta-Analyses: The PRISMA statement. PLOS Medicine 6, e1000097.

19. Jadad AR, Moore RA, Carroll D, et al. (1996) Assessing the quality of reports of randomized clinical trials: is blinding necessary? Control Clin Trials 17, 1-12.

20. Cerdá B, Soto C, Albaladejo MD, et al. (2006) Pomegranate juice supplementation in chronic obstructive pulmonary disease: a 5 -week randomized, double-blind, placebo-controlled trial. Eur J Clin Nutr 60, 245-253.

21. González-Ortiz M, Martínez-Abundis E, Espinel-Bermúdez MC, et al. (2011) Effect of pomegranate juice on insulin secretion and sensitivity in patients with obesity. Ann Nutr Metab 58, 220-223.

22. Shidfar F, Heydari I, Hajimiresmaiel SJ, et al. (2012) The effects of cranberry juice on serum glucose, apoB, apoA-I, Lp(a), and paraoxonase- 1 activity in type 2 diabetic male patients. $J$ Res Med Sci 17, 355-360.

23. Tjelle TE, Holtung L, Bohn SK, et al. (2015) Polyphenol-rich juices reduce blood pressure measures in a randomised controlled trial in high normal and hypertensive volunteers. Br J Nutr 114, 1054-1063.

24. Marcovina S, Bowsher RR, Miller WG, et al. (2007) Standardization of insulin immunoassays: report of the American Diabetes Association Workgroup. Clin Chem 53, 711-716.

25. Curtin F, Altman DG \&Elbourne D (2002) Meta-analysis combining parallel and cross-over clinical trials. I: continuous outcomes. Stat Med 21, 2131-2144.

26. Follmann D, Elliott P, Suh I, et al. (1992) Variance imputation for overviews of clinical trials with continuous response. J Clin Epidemiol 45, 769-773.

27. Higgins JPT \& Green S (editors) (2011) Cochrane Handbook for Systematic Reviews of Interventions, version 5.1.0 [updated March 2011]. The Cochrane Collaboration. http://handbook.cochrane.org

28. Sohrab G, Nasrollahzadeh J, Zand H, et al. (2014) Effects of pomegranate juice consumption on inflammatory markers in patients with type 2 diabetes: a randomized, placebo-controlled trial. J Res Med Sci 19, 215-220.

29. DerSimonian R \& Laird N (1986) Meta-analysis in clinical trials. Control Clin Trials 7, 177-188.

30. Egger M, Davey Smith G, Schneider M, et al. (1997) Bias in meta-analysis detected by a simple, graphical test. BMJ 315, 629-634.

31. United States Department of Agriculture Agricultural Research Service, Nutrient Data Laboratory (2016) USDA National Nutrient Database for Standard Reference, Release 28 (slightly revised). http://www.ars.usda.gov/ba/bhnrc/ndl 
32. Sohrab G, Angoorani P, Tohidi M, et al. (2015) Pomegranate (Punicagranatum) juice decreases lipid peroxidation, but has no effect on plasma advanced glycated end-products in adults with type 2 diabetes: a randomized double-blind clinical trial. Food Nutr Res 59, 28551.

33. Hollis JH, Houchins JA, Blumberg JB, et al. (2009) Effects of Concord grape juice on appetite, diet, body weight, lipid profile, and antioxidant status of adults. J Am Coll Nutr 28, 574-582.

34. Ravn-Haren G, Dragsted LO, Buch-Andersen T, et al. (2013) Intake of whole apples or clear apple juice has contrasting effects on plasma lipids in healthy volunteers. Eur J Nutr 52, 1875-1889.

35. Banini AE, Boyd LC, Allen JC, et al. (2006) Muscadine grape products intake, diet and blood constituents of non-diabetic and type 2 diabetic subjects. Nutrition 22, 1137-1145.

36. Codoñer-Franch P, López-Jaén AB, De La Mano-Hernández A, et al. (2010) Oxidative markers in children with severe obesity following low-calorie diets supplemented with mandarin juice. Acta Paediatr 99, 1841-1846.

37. Dohadwala MM, Hamburg NM, Holbrook M, et al. (2010) Effects of Concord grape juice on ambulatory blood pressure in prehypertension and stage 1 hypertension. Am J Clin Nutr 92, 1052-1059.

38. Guo H, Zhong R, Liu Y, et al. (2014) Effects of bayberry juice on inflammatory and apoptotic markers in young adults with features of non-alcoholic fatty liver disease. Nutrition 30, 198-203.

39. Habauzit V, Verny MA, Milenkovic D, et al. (2015) Flavanones protect from arterial stiffness in postmenopausal women consuming grapefruit juice for 6 mo: a randomized, controlled, crossover trial. Am J Clin Nutr 102, 66-74.

40. Krikorian R, Boespflug EL, Fleck DE, et al. (2012) Concord grape juice supplementation and neurocognitive function in human aging. J Agric Food Chem 60, 5736-5742.

41. Morand C, Dubray C, Milenkovic D, et al. (2011) Hesperidin contributes to the vascular protective effects of orange juice: a randomized crossover study in healthy volunteers. Am J Clin Nutr 93, 73-80.

42. Silver HJ, Dietrich MS \& Niswender KD (2011) Effects of grapefruit, grapefruit juice and water preloads on energy balance, weight loss, body composition, and cardiometabolic risk in free-living obese adults. Nutr Metab 8, 8 .

43. Tsang C, Smail NF, Almoosawi S, et al. (2012) Intake of polyphenol-rich pomegranate pure juice influences urinary glucocorticoids, blood pressure and homeostasis model assessment of insulin resistance in human volunteers. J Nutr Sci 1, e9.

44. Simpson EJ, Mendis B \& Macdonald IA (2016) Orange juice consumption and its effect on blood lipid profile and indices of the metabolic syndrome; a randomised, controlled trial in an at-risk population. Food Funct 7, 1884-1891.

45. Sumner MD, Elliott-Eller M, Weidner G, et al. (2005) Effects of pomegranate juice consumption on myocardial perfusion in patients with coronary heart disease. Am J Cardiol 96, 810-814.

46. Xi B, Li S, Liu Z, et al. (2014) Intake of fruit juice and incidence of type 2 diabetes: a systematic review and meta-analysis. PLOS ONE 9, e93471.

47. Tzulker R, Glazer I, Bar-Ilan I, et al. (2007) Antioxidant activity, polyphenol content, and related compounds in different fruit juices and homogenates prepared from 29 different pomegranate accessions. J Agric Food Chem 55, 9559-9570.

48. Nogata Y, Sakamoto K, Shiratsuchi H, et al. (2006) Flavonoid composition of fruit tissues of citrus species. Biosci Biotechnol Biochem 70, 178-192.

49. Bhagwat S, Haytowitz DB \& Holden JM (2014) USDA Database for the Flavonoid Content of Selected Foods, release 3.1, May 2014 update. US Department of Agriculture, Agricultural Research Service. http://www.ars.usda.gov/nutrientdata/flav

50. Vvedenskaya IO, Rosen RT, Guido JE, et al. (2004) Characterization of flavonols in cranberry (Vaccinium macrocarpon) powder. J Agric Food Chem 52, 188-195.

51. Xu Y, Simon JE, Welch C, et al. (2011) Survey of polyphenol constituents in grapes and grape-derived products. J Agric Food Chem 59, 10586-10593.

52. Peluso I \& Palmery M (2014) Risks of misinterpretation in the evaluation of the effect of fruit-based drinks in postprandial studies. Gastroenterol Res Pract 2014, 870547.

53. Berger VW \& Alperson SY (2009) A general framework for the evaluation of clinical trial quality. Rev Recent Clin Trials 4, 79-88. 